\title{
FUNGSI MESIN TRAKTOR DAN ALAT TRADISIONAL PENGOLAH TANAH
}

\author{
Indah Nurmayanti ${ }^{1}$, Mierza Aditya Nova ${ }^{2}$, Lukiana Norita ${ }^{3}$, Mahrus Ali $^{4 *}$, Siwidyah Desi \\ Lastianti $^{5}$ \\ 1,2,3 Universitas Muhammadiyah Gresik \\ ${ }^{4,5}$ Universitas Merdeka Surabaya \\ *Corresponding author Email: sengkomahrus@gmail.com
}

\begin{abstract}
ABSTRAK
Pengolahan tanah awalnya dilakukan secara konvensioal atau secara tradisional, dengan menggunakan tenaga hewan ternak (sapi, kerbau, dan kuda). Seiring dengan perkembangan zaman, pengolahan tanah konvensional diganti dengan pengolahan secara modern menggunakan teknologi yang canggih. Alat-alat sederhana yang umumnya digunakan untuk mengolah tanah seperti cangkul, parang, sabit dan lain-lain, sekarang diganti dengan bajak dan garu yang di gandengkan dengan traktor. Secara empiris zaman dulu manusia menggunakan tenaga hewan untuk membajak dan mengolah tanah. Sekarang tenaga hewan ternak tersebut telah digantikan dengan tenaga mesin. Sehingga pengolahan tanah menjadi lebih efisien dan efektif.Pengolahan tanah merupakan proses merubah sifat sifat fisik tanah dengan cara memotong, membalik, memecah, atau membongkar tanah, sehingga tanah dapat diolah untuk menanam. Pengertian lain, pengolahan tanah dalam usaha budidaya pertanian bertujuan untuk menciptakan keadaan tanah olah yang siap tanam baik secara fisis, kemis, maupun biologis, sehingga tanaman yang dibudidayakan akan tumbuh dengan baik. Pengolahan tanah terutama akan memperbaiki secara fisis, perbaikan kemis dan biologis terjadi secara tidak langsung. Implemet Traktor dibedakan berdasarkan tahap pengolahannaya yaitu pengolahan tanah pertama dan pengolahan tanah kedua. Masingmasing tahapan memiliki fungsi yang berbeda-beda. Pada pengolahan tanah pertama berfugsi untuk membalikan tanah, menghancurkan tanah dan membongkar tanah, alat-alat yang digunakan dalam pengolahan tanah pertama bajak singkal, baja piring, bajak rotari, bajak chisel dan bajak sub soil. Sedangkan pada pengolahan tanah kedua berfungsi menggemburkan dan meratakan tanah.
\end{abstract}

Kata Kunci: Mesin Traktor, Alat Tradisional, Pengolahan Tanah

\section{PENDAHULUAN}

Mekanisasi pertanian dalam arti luas bertujuan untuk meningkatkan produktifitas tenaga kerja, meningkatkan produktifitas lahan, dan menurunkan ongkos produksi. Penggunaan alat dan mesin pada proses produksi dimaksudkan untuk meningkatkan efisiensi, efektifitas, produktifitas, kualitas hasil, dan mengurangi beban kerja petani. Pengalaman dari negaranegara tetangga Asia menunjukkan bahwa perkembangan mekanisasi pertanian diawali dengan penataan lahan (konsolidasi lahan) (Pratiwi, Ali, Setiawan, Budiyanto, \& Sucahyo, 2017), keberhasilan dalam pengendalian air, masukan teknologi biologis, dan teknologi kimia. Proses pengolahan lahan berfungsi untuk menggemburkan tanah, menghilangkan kotoran, sampah dan gulma pada tanah. Proses pegolahan lahan meliputi tahap pembajakan dan penggaruan.

Pengolahan tanah awalnya dilakukan secara konvensioal atau secara tradisional, dengan menggunakan tenaga hewan ternak (sapi, kerbau, dan kuda). Seiring dengan perkembangan zaman, pengolahan tanah konvensional diganti dengan pengolahan secara 
modern menggunakan teknologi yang canggih. Alat-alat sederhana yang umumnya digunakan untuk mengolah tanah seperti cangkul, parang, sabit dan lain-lain, sekarang diganti dengan bajak dan garu yang di modifikasi dengan traktor. penggunaan pengolah tanah dengan menggunakan tenaga mesin lebih efisien dan efektif.

\section{HASIL DAN PEMBAHASAN 2.1 Pengolahan Tanah}

Sejak beribu-ribu tahun yang lalu pengolahan tanah telah dilakukan oleh sekelompok manusia dengan tujuan untuk meningkatkan produksi pertanian. Tenaga hewan digunakan untuk membajak tanah sejak 7000 tahun yang lalu.

Telah diketahui bahwa pengolahan tanah dapat merubah dan memperbaiki struktur tanah serta memberantas gulma. Perbaikan struktur tanah dengan pengolahan tanah diduga dapat berpengaruh baik pada pertumbuhan tanaman, meskipun demikian pendapat tersebut sulit dibuktikan karena hanya melihat aspek fisik tanahnya saja tanaman.

Perkembangan selanjutnya menunjukkan bahwa penelitian-penelitian mengenai pengolahan tanah terbagi dalam dua aliran, yaitu aliran yang memberikan penekanan pada pengendalian gulma dan aliran yang memberikan penekanan pada perbaikan struktur tanah (Hariyadi, Ali, \& Nurlina, 2017). Terlepas dari ada tidaknya pengaruh pengolahan tanah pada produksi tanaman, pengolahan tanah sampai kini tetap saja dilakukan petani paling tidak untuk mempermudah pekerjaan berikutnya.

\subsection{Alat Pengolahan Tanah Tradisional}

1. Cangkul

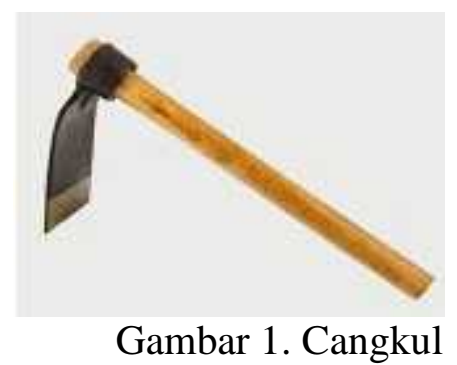

Cangkul atau Pacul adalah satu jenis alat pertanian tradisional yang digunakan dalam proses pengolahan tanah pada lahan pertanian. Cangkul digunakan untuk menggali, mencungkil, ataupun untuk meratakan tanah. Cangkul masih digunakan sehingga masa ini untuk menjalankan kerja-kerja menggali yang ringan di kebun ataupun di sawah. Alat ini merupakan elemen penting dalam bidang pertanian terutama pertanian ladang kering.

Fungsi tangkai cangkul : Untuk memegang dan mengayunkan mata cangkul sewaktu digunakan dalam bekerja.

Bagian-bagian cangkul : Bagian tangkai dari kayu bentuk tangkai lurus dan bengkok, bagian mata cangkul dari besi.

Fungsi mata cangkul : membalik tanah, menghaluskan tanah, mencampur pupuk. Ukuran dan bentuk cangkul bervariasi hal ini tergantung pada kondisi dan jenis tanah setempat.

1. Langa atau Langai 


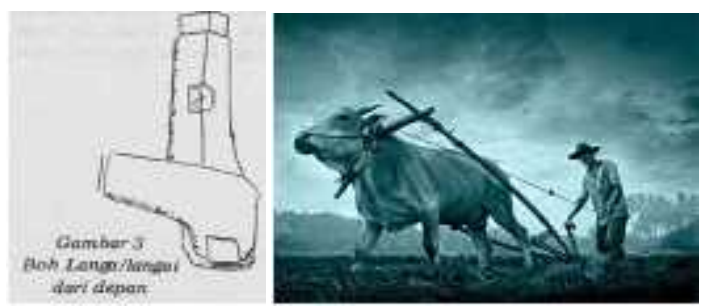

Gambar 2. Langa

Langai, Bajak Sawah Tradisional Aceh Langai atau disebut juga Langa merupakan istilah lokal masyarakat Aceh untuk menyebut bajak. Peralatan tradisional ini digunakan para petani Aceh untuk menggemburkan lahan pertanian agar mudah ditanami. Langa terdiri dari beberapa bagian dan terbuat dari kayu. Pengoperasian peralatan tersebut menggunakan tenaga sapi atau kerbau. Membajak (me'ue), merupakan pekerjaan utama dari rangkaian pengolahan lahan pertanian sebelum ditanami. Orang yang melakukan pekerjaan membajak disebut ureung me'ue. Tenaga yang digunakan untuk menarik langa berbeda antara lahan yang mengandung banyak air dan lahan yang kering.

Bagian-bagian Langa Langa terdiri dari bagian-bagian yang mempunyai nama masing-masing. Berikut adalah bagian-bagian langa.

a. Boh Langa

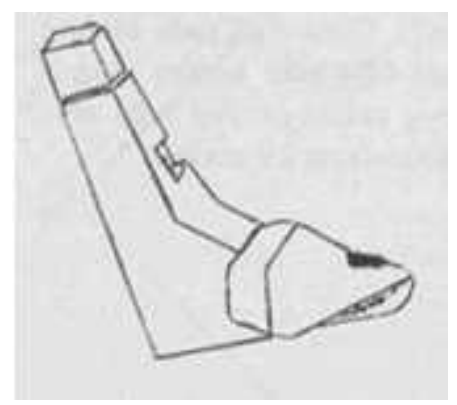

Gambar 3. Boh Langa

Boh Langa merupakan bagian yang terletak di paling bawah langa. Fungsi bagian ini adalah sebagai tempat memasang mata langa. Boh Langa terbuat dari kayu (bak mane). Mata Langa dipasang pada Boh Langa. Bentuk lancip mata langa mengikuti bentuk Boh Langa yang menyerupai anak panah besar. Bagian inilah yang mengorek atau membalik tanah ketika langa ditarik sehingga tanah menjadi gembur.

b. Eh Langa

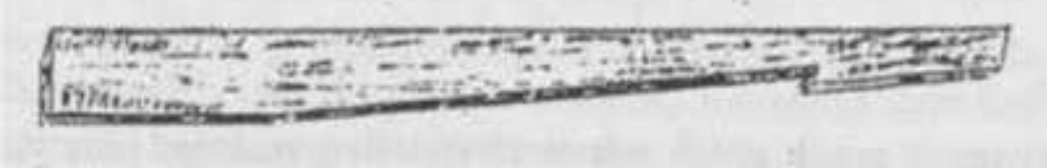

Gambar 4. Eh Langa

Eh Langa juga merupakan bagian penting dari peralatan ini. Eh Langa berfungsi untuk menghubungkan kerbau atau sapi penarik langa dengan bagian lain yang berada di belakangnya, yaitu bagian Boh Langa dan Yok Langa. Eh Langa terbuat dari sepotong kayu yang keras dan kuat, misalnya batang pohon aren. Eh Langa mempunyai panjang sekitar 2,5 meter dengan lebar sekitar 10-12 cm dan membujur dari depan ke belakang. Bagian belakang peralatan ini ada yang dibuat melengkung ke bawah, ada pula yang hanya lurus dari ujung ke 
pangkal. Untuk Eh Langa yang dibuat melengkung bagian belakangnya, ketika digunakan setengah batang Eh Langa akan berbentuk mendatar. Sedangkan jika Eh Langa dibuat lurus dari bagian depan sampai ke bagian belakang, batang Eh Langa akan berbentuk miring ketika digunakan dengan bagian depan berada di atas. Pada ujung peralatan ini dibuat lekukan yang dipakai untuk memasang tali. Lebar bagian ujung berbeda dengan bagian pangkal. Bagian ujung lebih sempit, sehingga bentuk Eh Langa mengerucut ke depan. Biasanya bagian yang menyempit dibuat pada bagian bawah Eh Langa.

c. Yok Langa

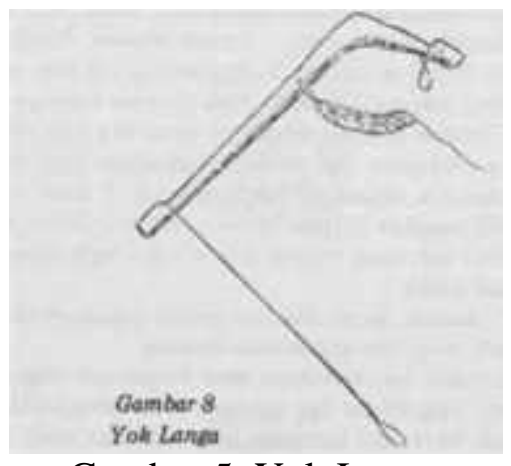

Gambar 5. Yok Langa

Yok Langa dibuat dari bahan kayu dengan bentuk khas. Bentuknya menyesuaikan dengan punggung sapi atau kerbau di mana Yok Langa akan dipasang. Fungsi Yok Langa adalah mengangkut Eh Langa yang ditarik sapi atau kerbau. Di atas bagian Boh Langa, terdapat peralatan lain, yaitu sepotong kayu yang dihaluskan. Kayu ini disebut lamat. Panjang lamat sekitar 1,5 meter. Lamat terletak di bagian paling belakang peralatan langa. Lamat berbentuk miring dan berfungsi sebagai pegangan orang yang menggunakan langa. Ureung mau'e menekan bagian ini agar mata langa terbenam ke dalam tanah. Selain itu, lamat juga berfungsi sebagai tempat para petani mengendalikan dan mengatur arah langa berbelok ke kanan, ke kiri atau memutar.

Selain beberapa bagian yang telah disebutkan di atas, langa juga mempunyai bagian tambahan. Di antara bagian tambahan dalam langa, yaitu: Dua helai tali yang terbuat dari sabut kelapa atau tali ijuk. Tali tersebut berguna untuk mengarahkan sapi atau kerbau agar berbelok ke kanan atau ke kiri. Tali tersebut membentang dari depan ke belakang, menghubungkan ureung mau'e dengan sapi atau kerbau penarik langa. Untuk mengarahkan sapi agar mau membelok ke kanan, urang mau'e akan menarik tali sebelah kanan. Begitu pula sebaliknya. Cambuk, yang terbuat dari kayu kecil atau sejenis kulit kayu. Cambuk berfungsi untuk memukul sapi atau kerbau agar mau berjalan atau menarik bajak. Anyaman dari rotan selebar telapak tangan. Fungsi anyaman ini adalah menghubungkan bagian Yok Langa yang terdapat di bawah leher sapi atau kerbau.

3. Bajak

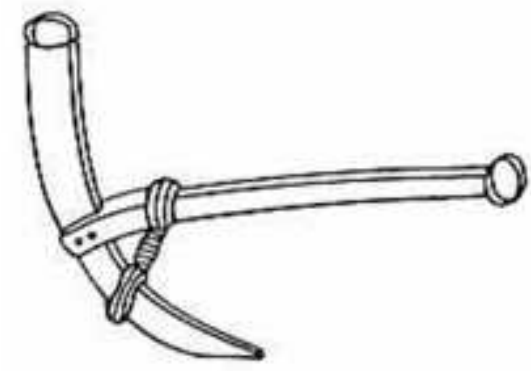


Lebih dari 2000 tahun yang lalu ditemukan bajak terbuat dari besi yang diproduksi di Honan utara China. Pada awalnya alat ini berupa alat kecil yang ditarik dengan tangan dengan plat besi berbentuk $\mathrm{V}$ yang dihubungkan atau digandengkan dengan pisau kayu dan pegangan. Bajak telah digunakan juga di India selama beribu-ribu tahun. Peralatan kuno tidak beroda dan moldboard terbuat dari kayu yang ditarik oleh sapi. Dengan alat ini tanah hanya dipecahkan kedalam bentuk clods tetapi tidak dibalik; dan pengolahan pertama ini kemudian diikuti dengan penghancuran "clod" dan perataan tanah dengan alat barupa batang kayu berbentuk empat persegi panjang yang ditarik oleh sapi.

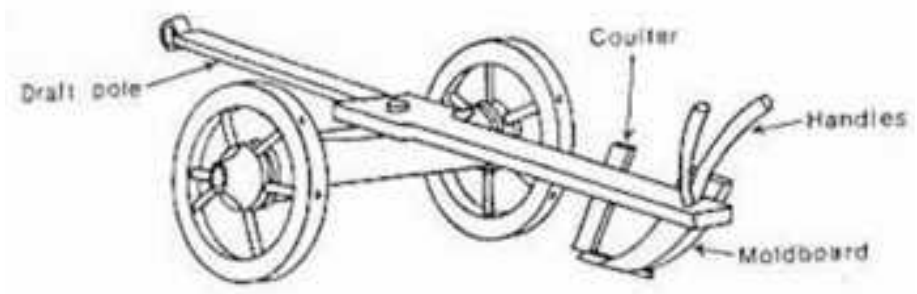

Gambar 7. Bajak beroda dua dengan coulter dan moldboard.

\section{Garu (Harrow)}

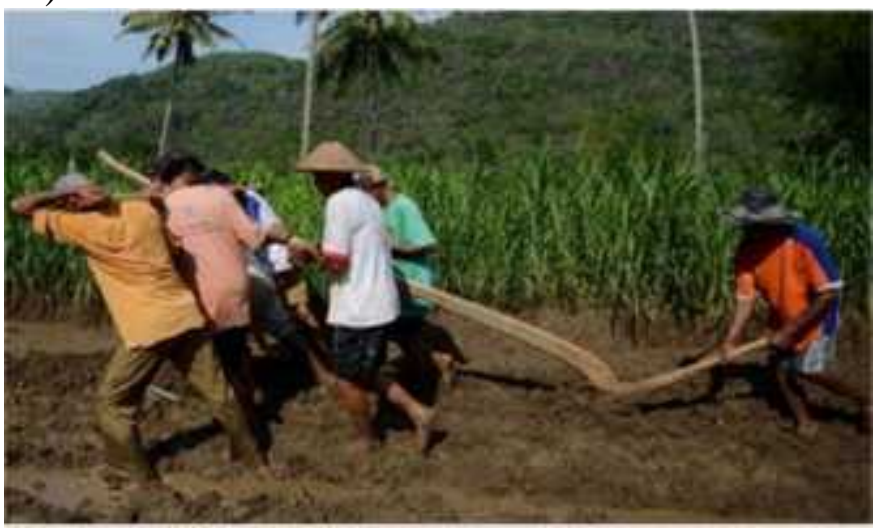

Gambar 8. Garu

Penggunaan garu sebagai pengolah tanah kedua, selain bertujuan untuk menghancurkan dan meratakan permukaan tanah, juga bertujuan untuk mengawetkan lengas tanah dan meningkatkan kandungan unsur hara pada tanah dengan jalan lebih menghancurkan sisa-sisa tanaman dan mencampurnya dengan tanah.

5. Cetok Tanah

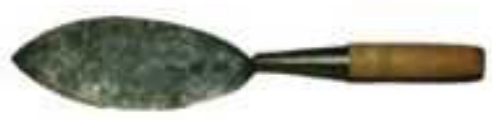

Gambar 9. Cetok Tanah

Cetok Tanah digunakan sebagai perata tanah dan pencongkel tanah pada sebuah kebun. Terdapat 2 jenis bahan, yaitu yang terbuat dari plat besi dan yang terbuat dari plat baja. Pegangan terbuat dari kayu.

\subsection{Macam dan Jenis Alat Pengolahan Tanah}


Macam dan jenis alat pengolahan tanah untuk pertanian digolongkan menjadi 2 golongan menurut tahap pengolahan tanahnya, yaitu : alat pengolah tanah pertama dan alat pengolah tanah kedua

Kedua golongan alat pengolah tersebut juga digolongkan menurut sumber tenaga atau tenaga penarik yang digunakan. Sumber tenaga atau tenaga penarik terdiri dari tenaga manusia, tenaga hewan, dan tenaga traktor.

\section{1) Alat pengolah tanah pertama}

Macam alat pengolah tanah pertama yang umum digunakan adalah cangkul, garpu, bajak singkal (Moldboard plow), bajak piring (Disc plow) dan bajak rotary (Rotary plow).

\section{a) Bajak Singkal}

Bajak singkal termasuk jenis bajak yang paling tua. Di Indonesia jenis bajak singkal inilah yang paling umum digunakan oleh petani untuk melakukan pengolahan tanah mereka, dengan menggunakan tenaga ternak sapi atau kerbau, sebagai sumber daya penariknya. Bajak singkal merupakan peralatan pertanian untuk pengolahan tanah yang digandengkan dengan sumber tenaga penggerak. Penarik seperti tenaga penarik sapi, kerbau atau traktor pertanian. Bajak singkal berfungsi untuk memotong, membalikkan, pemecahan tanah serta pembenaman sisa-sisa tanaman kedalam tanah, dan digunakan untuk tahapan kegiatan pengolahan tanah pertama. Bajak singkal dirancang dalam beberapa bentuk untuk tujuan agar diperoleh kesesuaian antara kondisi tanah dengan tujuan pembajakan. Aneka ragam rancangan yang dijumpai selain pada bentuk mata bajak, juga di bagian perlengkapannya. Mata bajak adalah bagian dari bajak yang berfungsi aktif untuk mengolah tanah. Bajak singkal ditujukan untuk pemecahan segala jenis tanah dan cocok sekali untuk pembalikan tanah serta penutupan sisa-sisa tanaman. Berdasarkan arah lemparan lempengan tanah, bajak singkal dibedakan menjadi dua tipe, yakni :

1. Bajak singkal satu arah adalah jenis bajak singkal dimana pada waktu mengerjakan pengolahan tanah akan melempar dan membalik tanah hanya dalam satu arah. Lemparan atau pembalikan tanahnya biasanya dilakukan ke arah kanan.

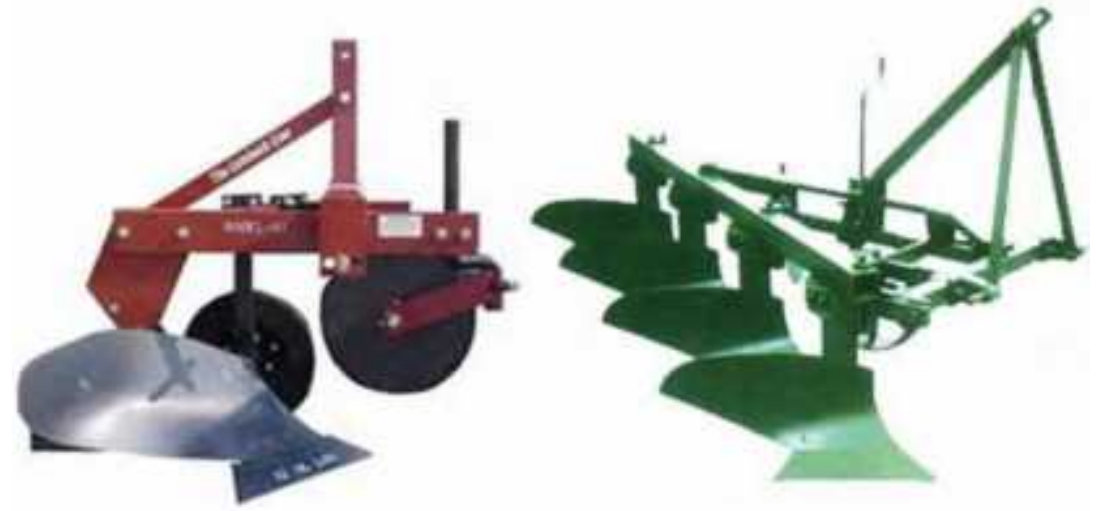

Gambar 10. Bajak Singkal Satu Arah

Traktor yang digunakan sebagai tenaga penarik pada umumnya bertenaga antara $15-25 \mathrm{Hp}$ untuk traktor mini empat roda dan 45-80 Hp untuk traktor roda besar empat roda. Jumlah bajak yang ditarik dengan traktor tangan biasanya hanya satu bajak. Traktor mini empat roda biasanya menarik 1 sampai 2 bajak. Sedangkan untuk traktor besar empat roda bervariasi, bisa menarik 3 sampai 8 bajak, bahkan bisa lebih dari itu.

2. Bajak singkal dua arah adalah jenis bajak singkal dimana pada waktu mengerjakan pengolahan tanah, arah pelemparan atau pembalikan tanahnya dapat diatur dua arah yaitu ke kiri maupun ke arah kanan. Jenis bajak ini mempunyai mata bajak yang kedudukannya dirancang untuk dapat diputar ke kanan ataupun ke kiri dengan cepat, sesuai dengan arah pelemparan ataupun pembalikan tanah yang dikehendaki. 


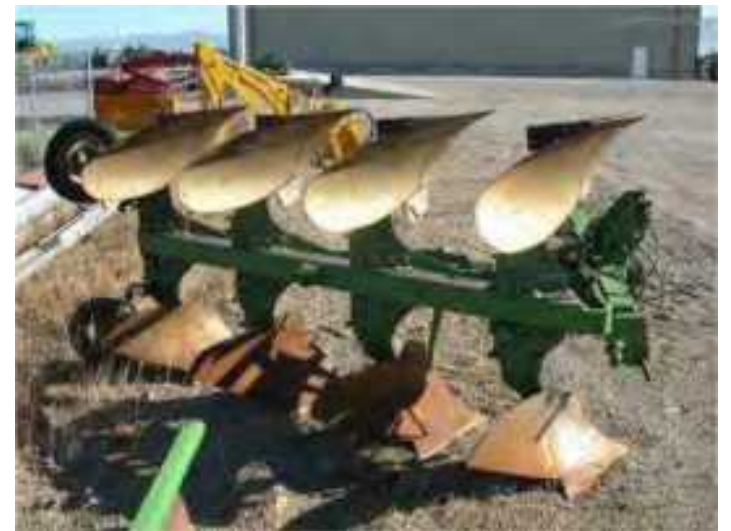

Gambar 11. Bajak Singkal Dua Arah (empat singkal)

Penggunaan bajak singkal dua arah mempunyai beberapa kelebihan, yaitu akan menghasilkan pembalikan tanah yang seragam untuk seluruh petak tanah yang diolah, praktis untuk pengolahan tanah sistem kontur dari hasil kerjanya tidak akan berbentuk alur mati (deadfurrow) ataupun alur punggung (back-furrow), sehingga pembajakan dapat teratur dan rata. Namun kelemahannya adalah konstruksinya lebih berat dan lebih rumit, untuk ukuran bajak yang besar perlu dilengkapi sistem hidrolis untuk pemutaran mata bajaknya, perlu keterampilan yang lebih baik dari pengemudinya.

b) Bajak Piring

Bajak piring berbentuk piringan, yaitu bulat dan cekung menyerupai alat penggorengan dengan garis tengah berkisar antara 60 sampai $80 \mathrm{~cm}$. Bajak jenis ini hanya bias ditarik oleh traktor besar empat roda saja, jumlahnya antara 3 sampai 8 bajak piring tergantung pada tenaga traktornya.

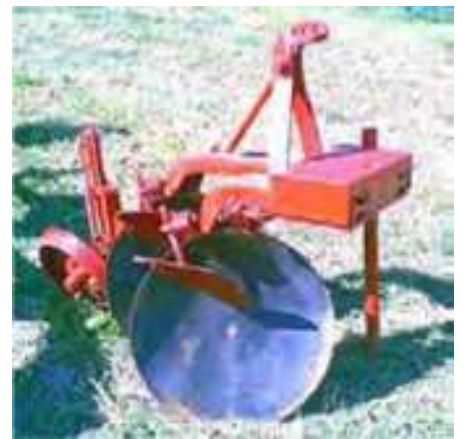

Gambar 12. Bajak Piring (2 piringan)

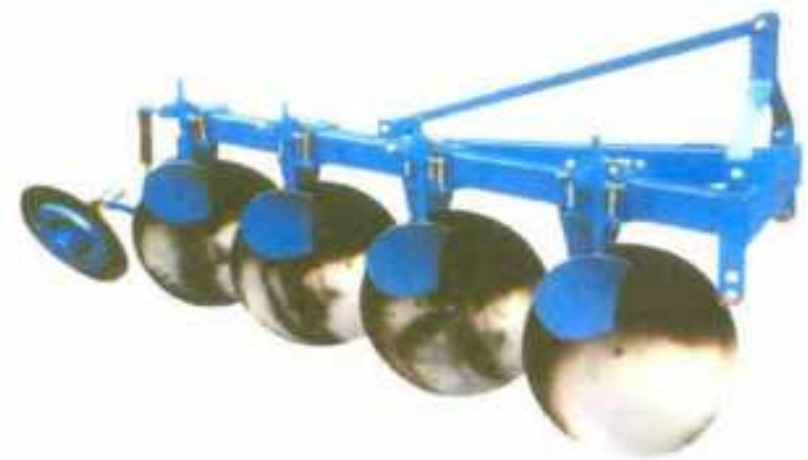

Gambar 13. Bajak Piring (4 piringan)

c) Bajak putar (rotary plow) 


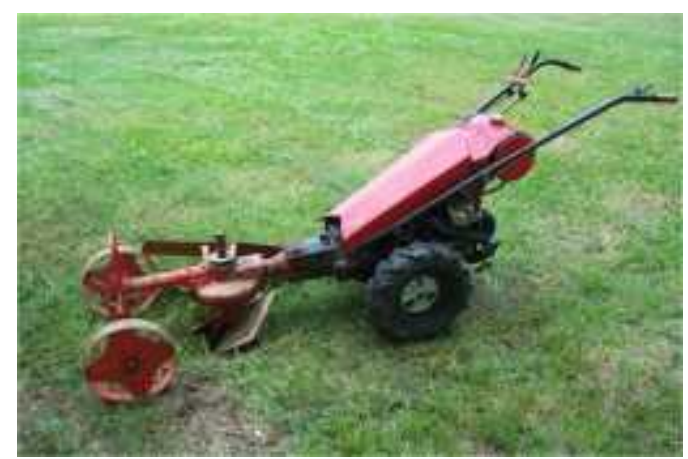

Gambar 14. Bajak putar (rotaru plow)

Pengolahan tanah dengan menggunakan bajak, akan diperoleh bongkah-bongkah yang masih cukup besar, biasanya masih diperlukan tambahan pengerjaan untuk mendapatkan keadaan tanah yang lebih halus lagi. Dengan menggunakan bajak putar maka pengerjaan tanah dapat dilakukan sekali tempuh. Bajak putar/bajak rotary dapat digunakan untuk pengolahan tanah kering ataupun tanah sawah. Kadang-kadang bajak putar ini digunakan untuk mengerjakan tanah kedua dan juga dapat digunakan untuk melakukan penyiangan ataupun pendangiran. Penggunaan bajak putar untuk pengolahan tanah dapat diharapkan hasilnya baik, bila tanah dalam keadaan cukup kering atau basah sama sekali.

Untuk mengatasi lengketnya tanah pada pisau dapat dilakukan dengan mengurangi jumlah pisau dan mempercepat putaran dari rotor dan memperlambat gerakan maju. Makin cepat perputaran rotor akan lebih banyak daya yang digunakan tetapi diperoleh hasil penggemburan yang lebih halus. Dalam penggunaan, dipilih kebutuhan daya yang terkecil tetapi memenuhi persyaratan ukuran partikel tanah yang dituntut oleh tanaman. Salah satu masalah dari penggunaan bajak putar ialah apabila di dalam tanah terdapat benda-benda keras: untuk itu biasanya diadakan pengamanan (dilengkapi per-per pada pisaunya, adanya pengamanan slip pada mesinnya). Berdasarkan atas sistem pengambilan daya untuk menggerakkan rotor dan pisau dari bajak putar, jenis bajak putar secara garis besar dibedakan menjadi dua, yaitu:

1. bajak putar dengan tenaga pemutar pisau dari mesin tersendiri terpisah dari tenaga traktor sebagai sumber daya penariknya (self propelled unit).

2. bajak putar dengan tenaga pemutar pisau dati pto traktor, yang sekaligus traktor tersebut sebagai sumber daya penariknya (pto drives tractor).

Prinsip kerja bajak putar

Pisau-pisau dipasang pada rotor secara melingkar hingga beban terhadap mesin merata dan dapat memotong tanah secara bertahap. Pada waktu rotor berputar dan alat bergerak maju pisau akan memotong tanah. Luas tanah yang terpotong dalam sekali pemotongan tergantung pada kedalaman dan kecepatan maju. Gerakan putaran rotor yang memutar pisau-pisau diakibatkan daya dari motor yang diteruskan melalui sistem penerusan daya khusus sampai ke rotor tersebut. Sistem penerusan daya untuk ukuran bajak putar kecil yang digerakkan dengan traktor tangan biasanya menggunakan sistem hubungan roda cakra dengan rantai. Untuk bajak putar ukuran besar yang digerakkan dengan traktor besar, biasanya menggunakan universal joint.

Bagian-bagian bajak putar

1. Pisau, berfungsi untuk mencacah tanah pada waktu pengolahan tanah dengan bajak putar dilakukan. Pisau ini juga cukup baik untuk mencacah gulma maupun seresah, namun tidak dapat menutupnya dengan tanah secara baik seperti bila menggunakan bajak singkal maupun bajak piringan. Besar dan jumlah pisau disesuaikan dengan daya penggerak dan keperluannya. Cara pemasangan pisau dalam hubungannya dengan bentuk permukaan dan hasil pengolahan tanah dapat dilihat pada gambar. 
2. Poros putar, berfungsi untuk memutar rotor-rotor bajak putar.

3. Rotor, berfungsi sebagai tempat pemasangan pisau-pisau dari bajak putar.

4. Penutup belakang (rear shield), berfungsi membantu penghancuran tanah.

5. Roda dukung (land wheel), berfungsi untuk mengatur kedalaman

Pengolahan Tanah.

1. Sistem pemasangan pisau

Pemasangan pisau dengan jumlah yang lebih sedikit akan memperoleh sedikit hambatan karena adanya seresah pada tanah dan pisau dapat masuk lebih dalam pada tanah sehingga seresah dapat bercampur dengan tanah. Juga dapat mengurangi kemungkinan macetnya alat pada waktu kerja di tanah yang basah dan lengket. Namun hasil pengolahan diperoleh bongkah yang lebih besar.

2. Tipe tanah

Pada tanah berat kandungan lempung lebih banyak, sehingga kohesi partikel tanah cukup besar hingga kemungkinan hasil pengerjaan tanah dapat bervariasi dari halus sampai kasar.

3. Kecepatan perputaran pisau

Pada kecepatan maju tetap, makin cepat perputaran pisau akan diperoleh pemotongan yang semakin halus; makin lambat perputaran pisau maka hasil pemotongan akan besar-besar. Pada kecepatan rendah, kemungkinan penyumbatan oleh tanah dan seresah makin besar tetapi kecepatannyya yang besar akan dapat merusak struktur tanah dan mengurangi umur pemakaian pisau.

4. Posisi penutup (rear shield)

Adanya penutup akan memungkinkan tanah lebih hancur karena tanah yang terlempar dari pisau terbentur pada penutup. Posisi dari penutup akan mempengaruhi benturan tanah terhadap pentup. Posisi yang memungkinkan adanya benturan yang lebih keras akan menghasilkan penghancuran tanah yang lebih besar.

5. Kandungan air tanah

Bila tanah dikerjakan pada kandungan air dimana ikatan partikel kecil maka hasil pengerjaan tanah akan lebih halus.

\section{d) Bajak pahat (chisel plow)}

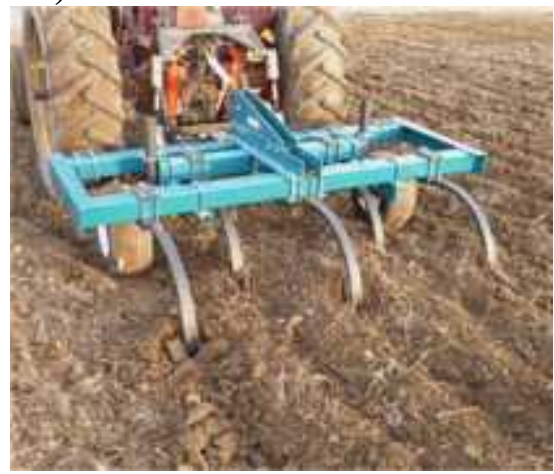

Gambar 15. Bajak Pahat (chisel plow)

Dalam pengerjaan tanah, bajak pahat dipergunakan untuk merobek dan menembus tanah dengan menggunakan alat yang menyerupai pahat atau ujung skop sempit yang disebut mata pahat atau chisel point. Mata pahat ini terletak pada ujung dari tangkai atau batang yang biasa disebut bar. Bar ini secara garis besar dapat dibagi menjadi dua macam, yaitu:

1. kaku, adalah konstruksi yang berat Jenis batang ini terbuat dari baja dengan kadar karbon tinggi. Batang ini mungkin berbentuk lurus mungkin juga berbentuk lengkung. 


\section{2. lentur (flexible)}

Ukurannya biasanya lebih panjang dan lebih ramping. Terbuat dari baja yang dicampur dengan nikel. Bekerja seperti aksi dari per. Batang (bar) ini dipasang pada kerangka yang mana jarak bar yang satu dengan yang lain masing-masing $\square 30 \mathrm{~cm}$, dapat juga antara $(30-60) \mathrm{cm}$ untuk ukuran bajak pahat yang besar. Bajak pahat ini dapat dipergunakan untuk pembajakan dangkal maupun dipergunakan untuk pembajakan dalam sampai kedalaman $45 \mathrm{~cm}$, tergantung pada keperluan dan jenis mata pahatnya. Berdasarkan jenisnya pula, lebar kerja alat sangat bervariasi tergantung dari sumber daya penarik dan keperluannya. Fungsi dari bajak pahat tidak sama dengan fungsi bajak singkal maupun bajak piringan.

Fungsi bajak pahat adalah:

a. Untuk memecah tanah yang keras dan kering, ini biasa dilakukan sebelum pembajakan untuk tanah tertentu.

b. Dipergunakan untuk pengerjaan praktis pada tanah bawah

c. Dipergunakan pada tanah yang berjerami, dan dipergunakan untuk memotong sisa-sisa perakaran yang berada dalam tanah.

d. Dipergunakan untuk memecah lapisan keras (hardpan) atau plow sole.

e. Untuk memperbaiki infiltrasi air pada tanah, sehingga dapat mengurangi erosi.

\section{e) Bajak Tanah Bawah (sub soil plow)}

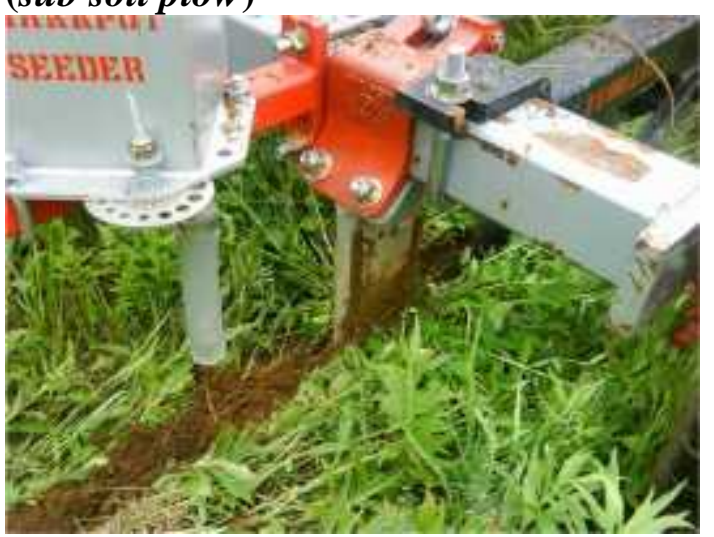

Gambar 16. Bajak Tanah Bawah (sub soil plow)

Bajak tanah bawah termasuk di dalam jenis bajak pahat tetapi dengan konstruksi yang lebih berat. Fungsi bajak ini tidak banyak berbeda dengan bajak pahat, namun dipergunakan untuk pengerjaan tanah dengan kedalaman yang lebih dalam, yaitu mencapai kedalaman sekitar (50 - 90) $\mathrm{cm}$. Untuk jenis standart tunggal biasanya dipergunakan untuk mengerjakan tanah dengan kedalaman sampai $90 \mathrm{~cm}$, sedang penarikannya menggunakan traktor dengan daya $(60$ - 85) HP. Kemudian untuk bajak tanah bawah jenis standart dua atau lebih, biasanya dipergunakan untuk pekerjaan yang lebih dangkal. Kadangkala pada bajak tanah bawah ini di bagian belakangnya dilengkapi dengan alat lain diantaranya:

1. Perlengkapan mole (mole attachment)

Alat ini digandengkan di belakang bajak tanah bawah. Alat ini berbentuk oval berdiameter $(7,5-20) \mathrm{cm}$. Hasilnya akan meninggalkan bekas seperti terowongan. Terowongan ini dimaksudkan untuk perbaikan drainase, kalau keadaan ideal akan tahan sampai 7 tahun.

2. Perlengkapan pemupukan (fertilizer attachment)

Penggandengan alat ini pada bajak tanah bawah dimaksudkan untuk sekaligus mengadakan pemupukan dengan kedalaman tertentu. Dalam kenyataannya, cara pemupukan dengan sistem ini mendapatkan hasil yang menggembirakan. Jarak alur biasanya $120 \mathrm{~cm}$, tapi jarak ini dapat divariasikan menurut keadaan dan keperluannya. 


\section{2) Alat Pengolah Tanah kedua}

Macam alat pengolah tanah kedua yang umumnya sering digunakan adalah : bajak rotary, garu sisir dan garu piring

a) Bajak Rotary (Rotary Plow)

Hasil pembajakan dengan bajak rotary memberikan tanah olah yang langsung hancur dan merata, karena bajak jenis ini terdiri dari pisau-pisau rotary yang berputar menghancurkan tanah.

Secara umum bajak rotary dapat digolongkan menjadi 2 jenis, yaitu :

1. Tenaga pemutar pisau roraty dari mesin tersendiri terpisah dari tenaga traktor

2. Tenaga pemutar pisau roraty disalurkan langsung dari tenaga putaran poros mesin traktor.

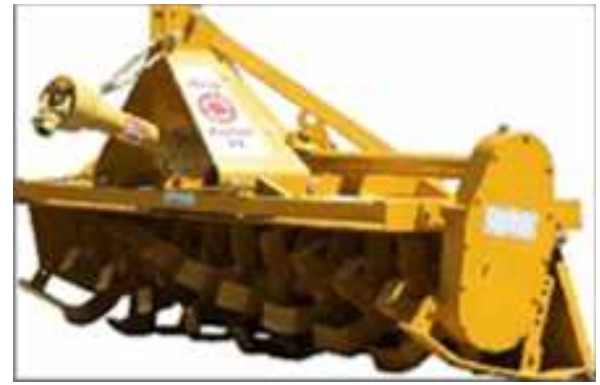

Gambar 17. Bajak Rotary Traktor Besar Empat Roda

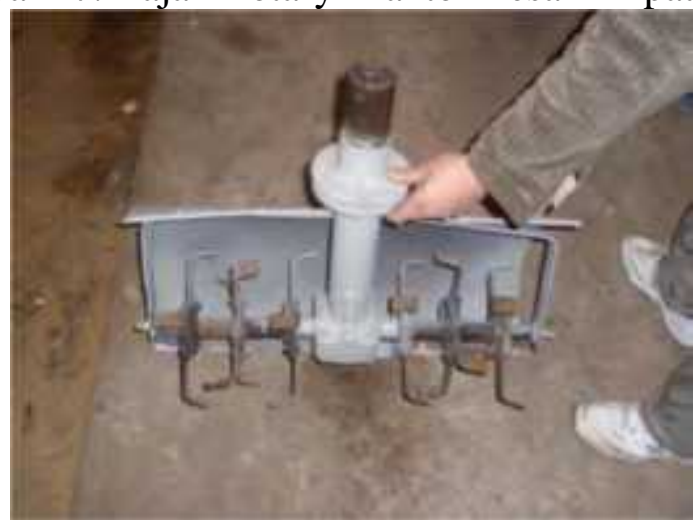

Gambar 18. Bajak Rotary Hand Traktor Roda Dua

Sedangkan untuk traktor besar empat roda sistem penyaluran tenaganya menggunakan sistem poros penyalur tenaga dari mesin power take off (PTO).

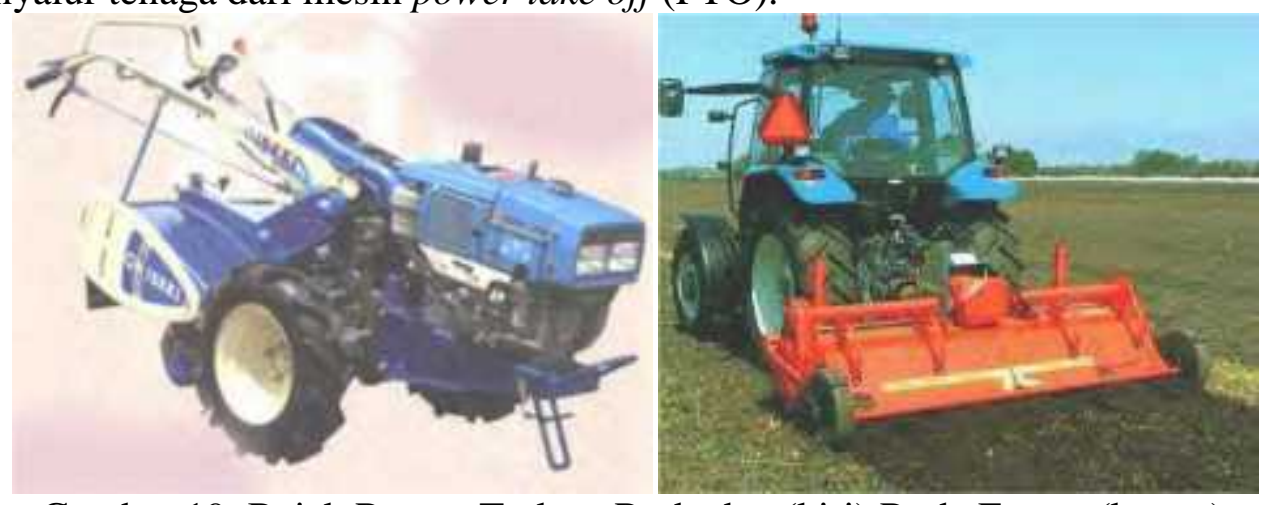

Gambar 19. Bajak Rotary Traktor Roda dua (kiri) Roda Empat (kanan)

b) Garu paku 
Garu ini mempunyai gigi yang bentuknya seperti paku terdiri dari beberapa baris gigi yang diikatkan pada rangka. Garu ini digunakan untuk menghaluskan dan meratakan tanah setelah pembajakan. Juga dapat digunakan untuk penyiangan pada tanaman yang baru tumbuh.

\section{c) Garu Pegas}

Garu pegas sangat cocok untuk digunakan pada lahan yang mempunyai banyak batu atau akar-akar, karena gigi-giginya yang dapat indenting (memegas) apabila mengenai gangguan. Kegunaan garu ini sama dengan garu paku, bahkan untuk penyiangan garu ini lebih baik, karena dapat masuk ke dalam tanah lebih dalam.

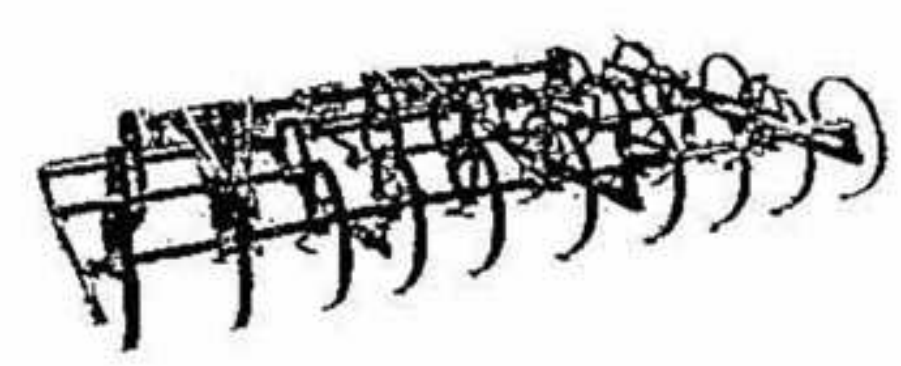

Gambar 20. Salah Satu Bentuk dari Garu Pegas

d) Garu Khusus

Yang termasuk kedalam garu khusus adalah weeder-mulche dan soil surgeon. Weedermulche adalah alat yang digunakan untuk penyiangan, pembuatan mulsa dan pemecahan tanah di bagian permukaan. soil surgeon adalah alat yang merupakan susunan pisau berbentuk U dipasang pada suatu rangka dari pelat. Alat ini digunakan untuk memecah bongkah-bongkah tanah di permukaan dan untuk meratakan tanah.

\section{e) Land Rollers dan Pulverizers}

Alat ini menyerupai piring-piring atau roda-roda yang disusun rapat pada satu as. Puingan piring dapat tajam atau bergerigi. Digunakan untuk penyelesaian dari proses pengolahan tanah untuk persemaian. Alat ini dapat digolongkan atas dua jenis yaitu ;

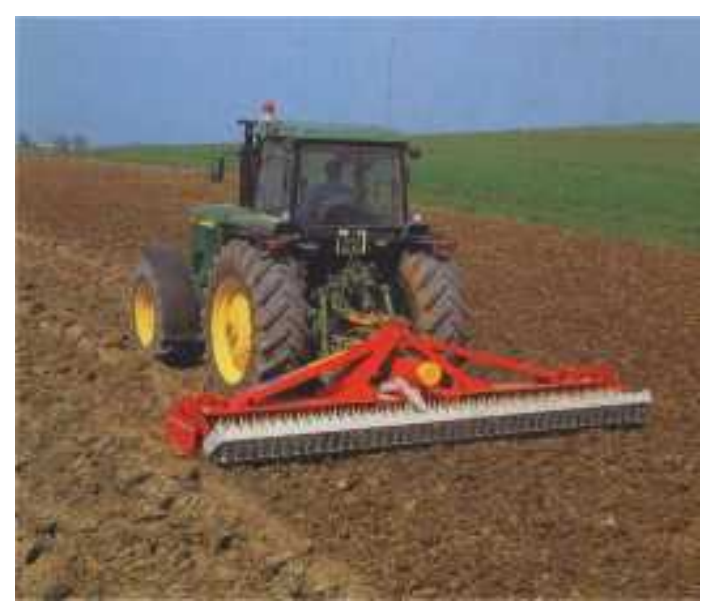

Gambar 21. Pulverizer 


\section{f) Garu Sisir}

Garu sisir dapat digunakan pada tanah sawah (basah) dan juga pada tanah kering. Kegunaan mata sisir adalah untuk menghancurkan, meratakan dan membenamkan sisa-sisa tanaman yang sudah terbajak.

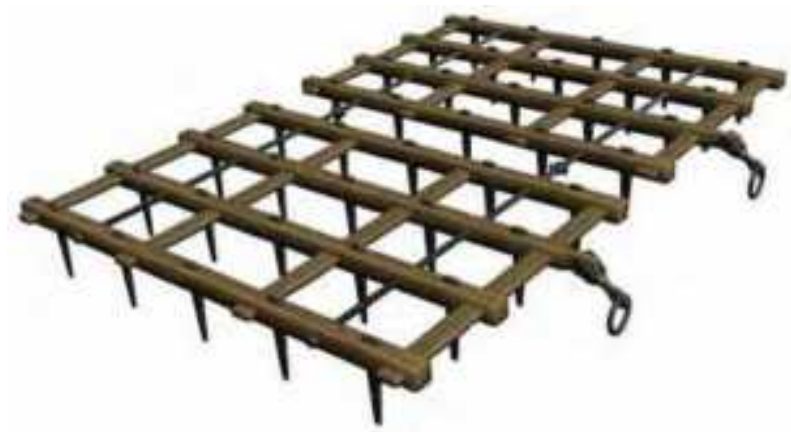

g) Garu Piring

Gambar 22. Garu Sisir Untuk Lahan Kering

Garu piring dapat berbentuk seperti bajak piring (rata tepinya) atau tepinya dapat juga berbentuk gelombang. Garu piring yang ditarik dengan traktor besar 4 roda, jumlah piringan dalam satu gang adalah 8 sampai 12 buah piringan, sedangkan jumlah gang dalam satu tarikan adalah 2 atau 4 gang. Diameter garu piring lebih kecil daripada bajak piring.

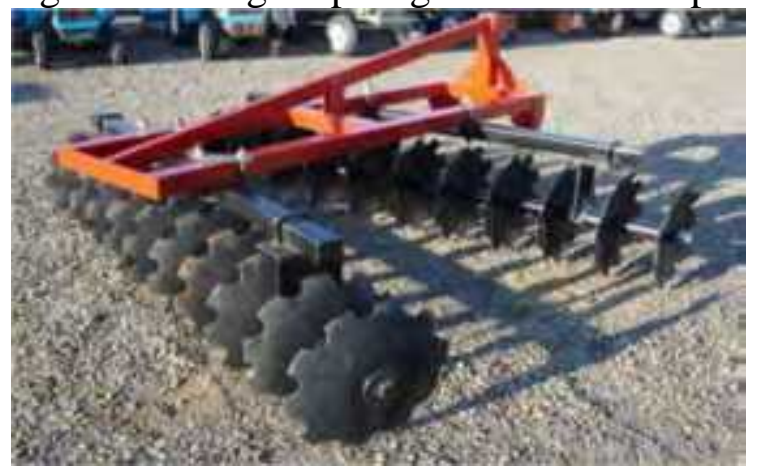

Gambar 23. Garu Piring (Disc Harrow) Tepi Bergelombang

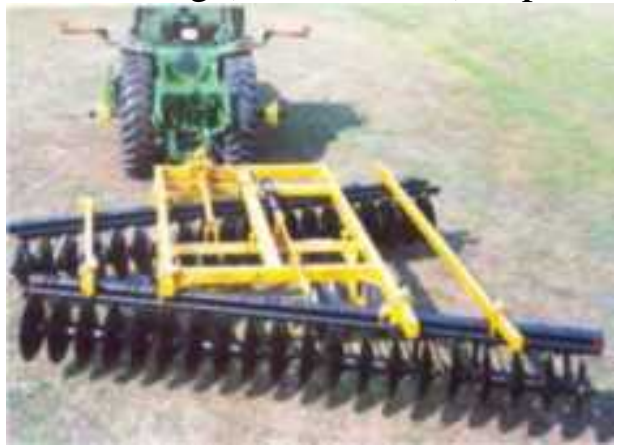

Gambar 24. Garu Piring Tepi Ratas

\subsection{Jenis - jenis Mesin Traktor}

\subsubsection{Traktor Tangan}

Traktor roda dua atau traktor tangan (power tiller/hand tractor) adalah mesin pertanian yang dapat dipergunakan untuk menngolah tanah dan lain-lain pekerjaan pertanian dengan alat pengolah tanahnya digandengkan/dipasang di bagian belakang mesin. Mesin ini mempunyai efesiensi tinggi, karena pembalikan dan pemotongan tanah dapat dikerjakan dalam waktu yang bersamaan. Traktor roda dua merupakan mesin serbaguna karena dapat juga berfungsi sebagai tenaga penggerak untuk alat-alat lain seperti pompa air, alat prosesing, gandengan (trailer). 


\subsubsection{Bagian-bagian Traktor Tangan}

1. Komponen utama traktor tangan

Komponen utama traktor tangan terdiri dari beberapa unit utama yaitu :

a. Unit Penggerak.

Traktor tangan umumnya menggunakan unit penggerak menggunakan motor satu selinder dengan daya antara $3 \mathrm{~s} / \mathrm{d} 12 \mathrm{HP}$.

b. Unit kerangka dan transmisi

Kerangka merupakan tempat kedudukan motor penggerak, unit transmisi dan bahagian traktor lainnya. Daya motor penggerak diteruskan ke roda traktor melalui putaran poros engkol ke kopling utama melalui sabuk V. Kopling utama meneruskan daya tersebut ke susunan roda gigi transmisi untuk menggerakkan poros roda dan PTO atau bahagian/alat lain yang bergerak. Putaran gigi dapat diatur/diubah dengan menggunakan kopling dan perubahan putaran (gas) dan lain-lain.

c. Unit Roda.

Bagian ini terdiri dari roda/ban dan bagian lain yang menjalankan traktor. Ban dapat berupa ban karet dengan berbagai tipe dan ukuran maupun roda besi. Tetapi pada unit-unit tersebut masih banyak bagian-bagian yang penting pada traktor tangan, untuk lebih jelasnya dapat dilihat pada Gambar di bawah ini.

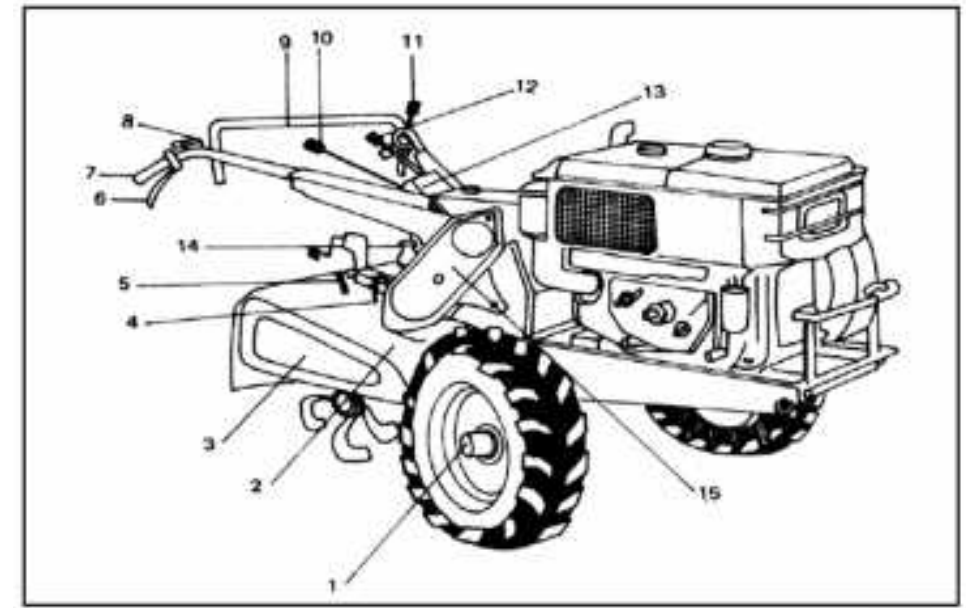

Gambar 25. Traktor tangan dan mama - nama bagianya samping kanan

Keterangan :

1. As Roda

2. Pelindung samping

3. Penahan Lumpur

4. Penahan Lumpur

5. Pengikat batang ridger

6. Handel pengikat roda belakang jalan

7. Tuas belok kanan

8. Handel utama
9. Tuas gas/akselerasi

10. Handel pembantu

11. Tongkat pemindah

kecepatan rotary

12. Tuas kopling utama

13. Tongkat pemindah kecepatan

14. Tuas penyangga depan

15. Gantungan pisau rotary 


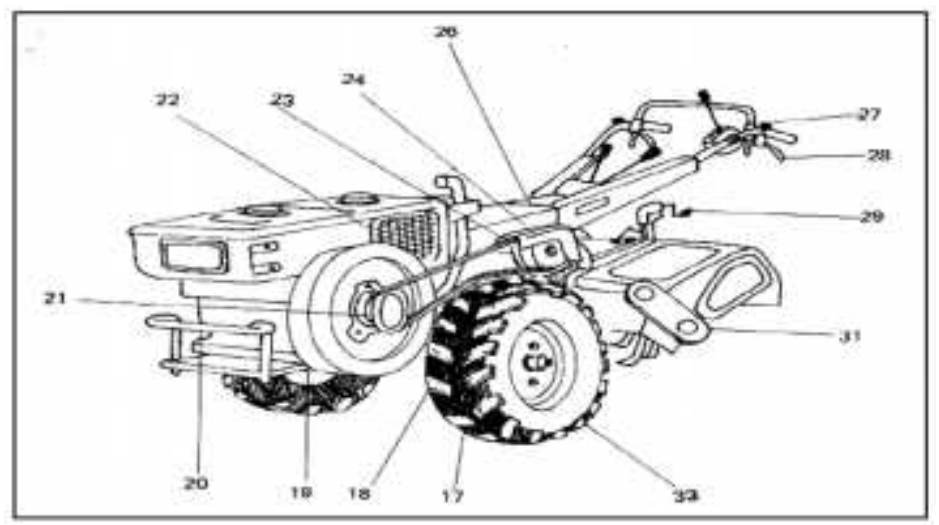

Gambar 26. Traktor tangan dan nama bagian - bagianya samping kiri Keterangan :

16. Kotak rantai pembantu

17. Pully penegang

18. Penyangga depan

19. Penyangga mesin

20. Pelindung depan

21.Pully mesin

22. V-belt

23.Pully utama
24. Pelindung v-belt

25. Tutup kotak peralatan

26. Tombol lampu

27. Tuas belok kiri

28. Pengatur roda belakang

29. Roda belakang

30. Ban

\subsubsection{Bagian-bagian penting traktor tangan dan fungsinya}

a. Tenaga penggerak / enjin

Tenaga penggerak selalu menggunakan internal combustion engine yang dapat dibedakan terutama dari bahan bakarnya, yaitu :

- Motor bensin

- Motor diesel

- Motor minyak tanah

- Motor bensin campur

Tenaga penggerak ini dipakai untuk menggerakkan/menarik peralatan pengolah tanah. Biasanya, motor yang digunakan mempunyai satu silinder.

b. Gigi transimsi

Gigi berfungsi memindahkan tenaga/putaran dari motor ke bagian/alat-alat lain yang bergerak. Putaran gigi dapat diubah dengan menggunakan kopling dan perubahan putaran (gas), dan lain-lain.

c. Bagian-bagian yang bergerak

Bagian-bagian ini terdiri atas roda-roda/ban dan bagian lain untuk menjalankan traktor roda dua tersebut. Roda besi dipergunakan untuk mengolah tanah di tanah yangt berair/sawah. Untuk tanah-tanah yang lebih lunak lagi, lebih baik menggunakan roda besi aping (floating wheel) yang diameternya lebih besar. Hal ini untuk mencegah terbenamnya traktor di sawah.

d. Unit kontrol

Unit control adalah alat-alat control yang dipasang pada traktor, seperti alat untuk menghidupkan, mematikan motor, mengubah putaran motor, mengubah gigi dan lain-lain.

e. Unit rem

Traktor dilengkapi dengan unit rem untuk keselamatan kerja. Unit rem biasanya merupakan rangkaian dari kopling.

f. Perlengkapan kerja/ implement traktor roda dua

Traktor roda dua selalu dilengkapi dengan alat-alat/implement untuk mengolah tanah seperti : 
1. Bajak (plow)

2. Bajak berputar (rotary)

3. Garu (harrow)

4. Penggulud (ridger)

5. Papan perata (leveller)

6. Roda besi

\section{Menyetel Bagian-bagian Penting Traktor Tangan}

1. Mengadakan pemeriksaan umum

a. Semua baut dan mur yang ada pada traktor harus diperiksa agar tidak kendur.

b. V-belt dan Fan-belt juga diperiksa. Ketegangan V-belt dan fan-belt harus sesuai. Untuk memeriksa apakah penyetelan ketegangan tali sudah baik atau belum, tekanlah tali itu dengan jari tangan sekitar $1,5 \mathrm{~cm}$ sampai $3 \mathrm{~cm}$.

c. Memeriksa kopling. Pada posisi OFF maka rotary atau traktor tidak berputar/bergerak, jika tidak maka berarti kopling tidak bekerja sempurna, maka perbaiki/setel dulu sebelum dioperasikan.

d. Traktor harus jalan lurus. Untuk memeriksa apakah traktor berjalan lurus, traktor harus dihidupkan enjinnya. Kemudian jalankan traktor dengan kecepatan rendah. Kalau penyetelan kopling kemudi (steering clutch) baik, maka traktor berjalan lurus ke depan.

e. Memeriksa tekanan ban. Untuk memudahkan traktor tangan dapat berjalan lurus adalah dengan menentukan tekanan angina yang sama pada kedua ban. Tekanan angin yang baik untuk tiap ban adalah sekitar 16,5 lbs per inchi.

\section{Memeriksa bagian-bagian yang perlu dilumasi}

a. Periksa oli mesin

Tutup oli pada karter dibuka dan di situ ada dipstick/tongkat penduga oli untuk memeriksa cukup/kotor tidaknya oli. Oli yang dipakai adalah oli SAE 30/40

b. Periksa oli gigi transmisi

Di samping tempat gigi transmisi biasanya terdapat jendela plastic untuk melihat apakah oli masih cukup dan baik. Oli yang digunakan adalah oli SAE 90

c. Periksa tempat rantai belakang (khusus traktor dengan implement rotary).

Oli yang digunakan adalah ali SAE 90. Oli dapat diisi dengan cara memutar penutupnya.

d. Periksa gemuk pada rantai pembantu (khusus traktor dengan implement rotary) Rantai pembantu ini berfungsi untuk memutarkan as/sumbu rantai utama. Untuk itu periksa gemuk untuk mencegah kemungkinan rantai dan lager/bantalannya cepat aus (rusak).

e. Melumasi kabel kopling pembelok

Kabel kopling pembelok perlu dilumasi agar dapat bekerja dengan lancer, baik, dan juga menghambat cepat putusnya kabel tersebut.

f. As pisau berputar (rotary)

Pada as pisau berputar terdapat tutup oli yang dapat dibuka. Melalui lubang ini oli SAE 30/40 diisi/diteteskan untuk melumasi putaran as/sumbu tersebut.

g. As/sumbu berputar

Setelah beberapa kali penggunaan, pisau berputar harus dibuka dari asnya. Kemudian as tersebut dilumasi dengan oli agar tidak karatan.

h. As kopling

Lumasi as kopling dengan beberapa tetas oli SAE 30.

i. Kabel standar

Kabel ini perlu dilumasi dengan oli agar licin. Caranya adalah oli diteteskan dan kabelnya ditarik-tarik/steering clutch-nya ditekan beberapa kali. Oli yang digunakan adalah ali SAE 90. Oli dapat diisi dengan cara memutar penutupnya.

j. Memeriksa sistem pendinginan 
Periksa air pada tangki pendingin, jika kurang tambahi.

k. Memeriksa perlengkapan (implement) dan kunci-kunci

\section{Mengoperasikan Traktor Tangan}

1. Cara kerja traktor tangan/ hand tractor

a. Tongkat untuk mengganti kecepatan bajak (rotary)

Jika dikehendaki tanah hasil bajakan kasar, maka harus mengganti kecepatan dari pisau bajak, pasanglah tuas pengatur kecepatan dari pisau bajak pada posisi "rendah", tetapi jika untuk menghasilkan hasil bajakan yang halus dan "gembur", pasanglah kecepatan pisaupisau bajak pada posisi "high". Pilihlah kecepatan yang tepat sehingga diperoleh efesiensi kerja tertinggi dari handtraktor tersebut.

b. Cara pemakaian persneling

- Persneling 1 dan 2 dipergunakan untuk membajak tanah yang lunak
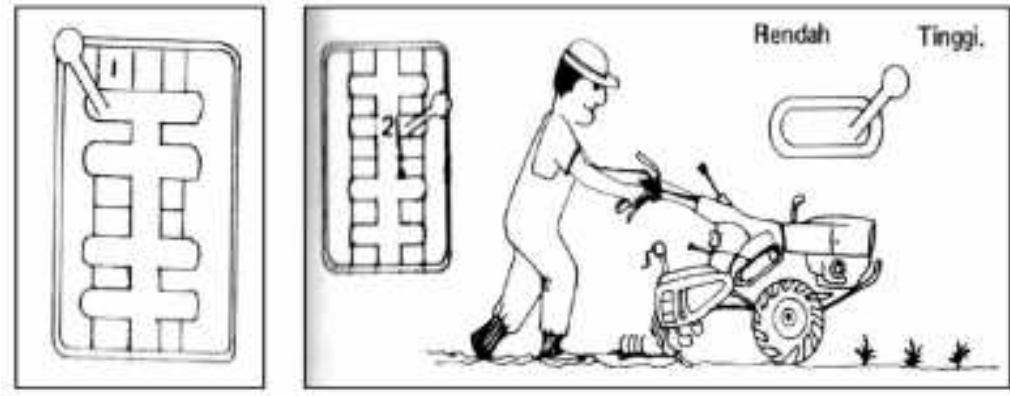

- $\quad$ Persneling3 dipergunakan untuk membajak, meratakan dan membalik tanah.

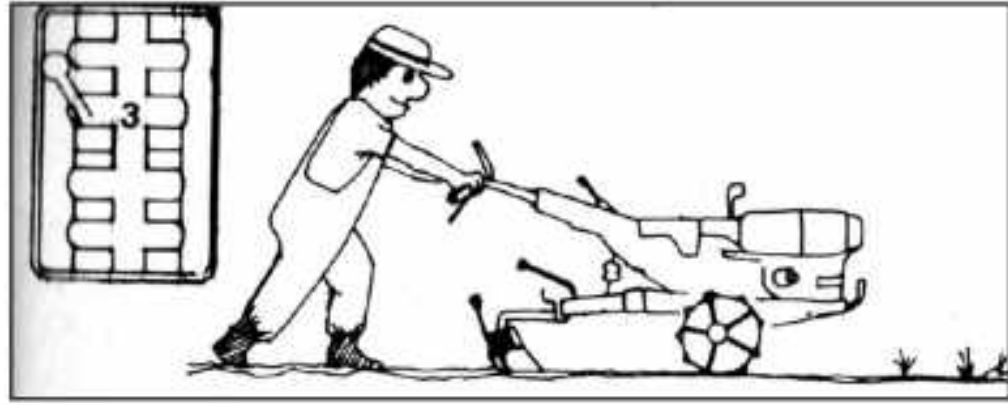

- Persneling4 dipergunakan untuk membajak sawah serta meratakannya.

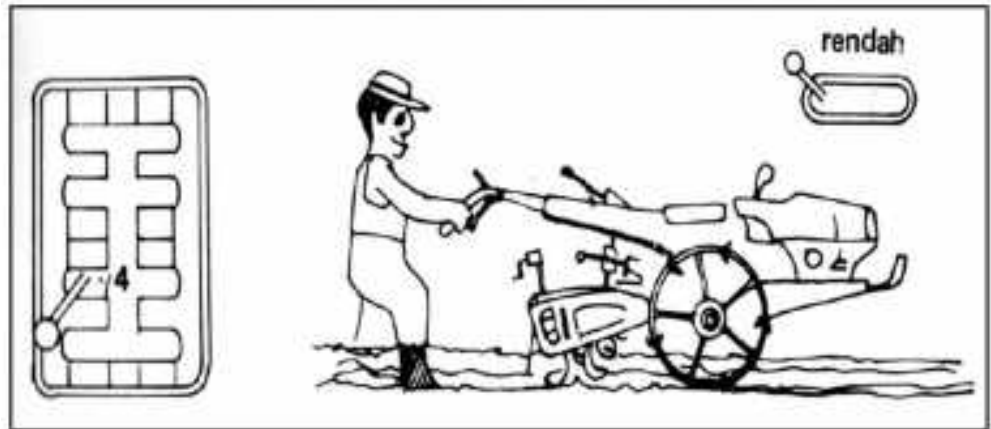

- Persneling5 dipergunakan untuk berjalan dijalan biasa.

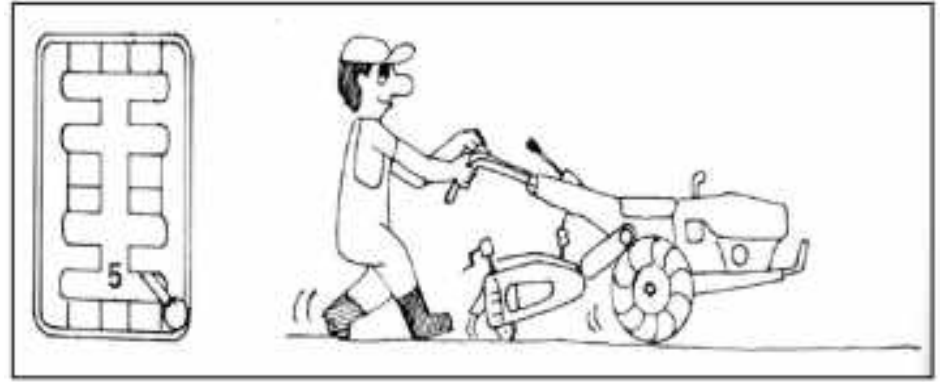


Persneling 6 dipergunakan untuk menarik gerobak barang/ mengangkut barang serta kendaraan transport.

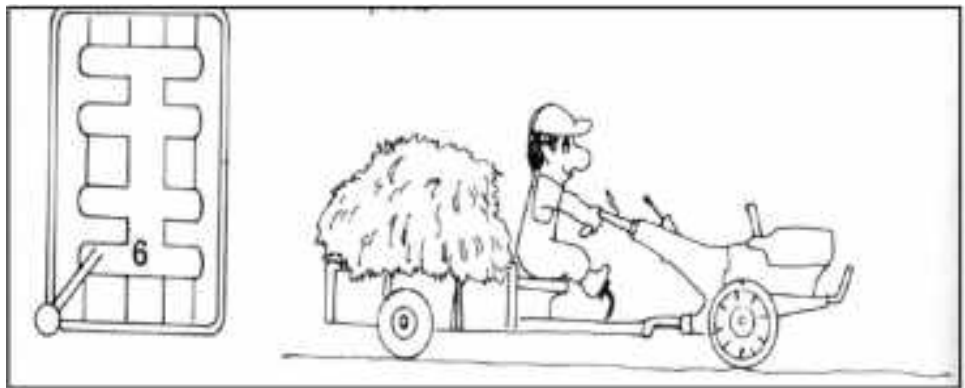

c. Alat pengemudi pada stang stir

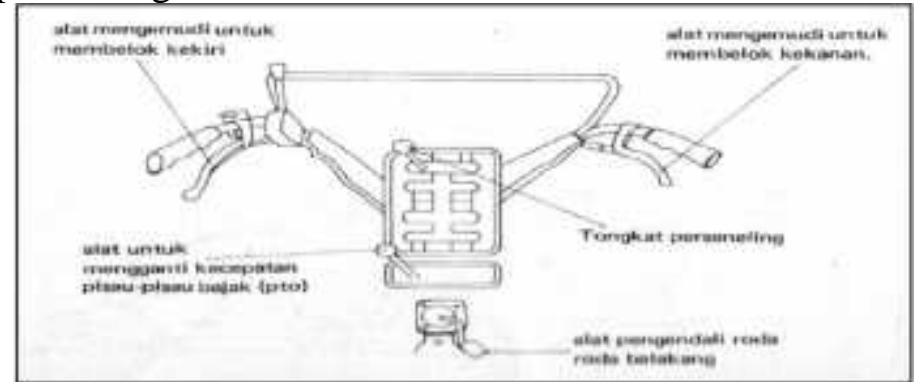

d. Tongkat pengendali roda belakang

Kedalaman bajakan dapat dikendalikan dengan cara memutar tangkai pengendali rodaroda belakang. Jika tangkai pengendali roda belakang diputar kekanan, bajakan akan dalam dan sebaliknya.

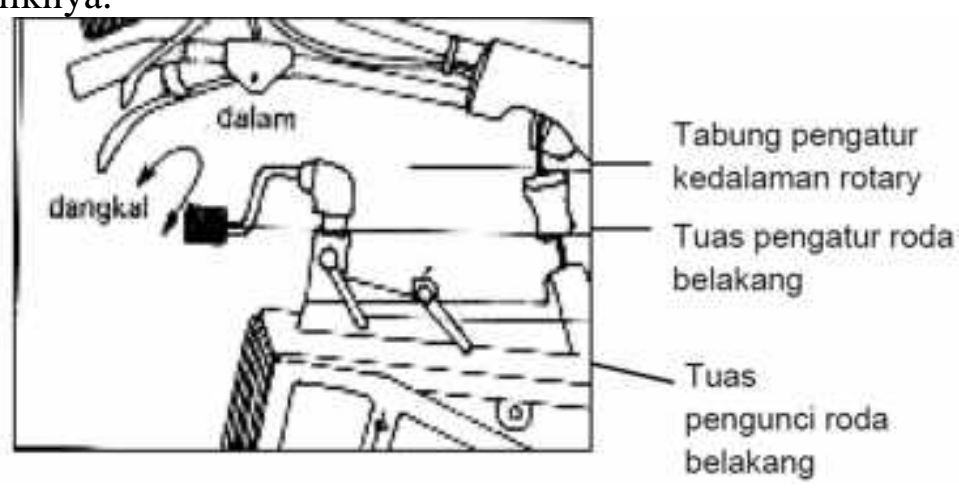

e. Tuas kopling utama

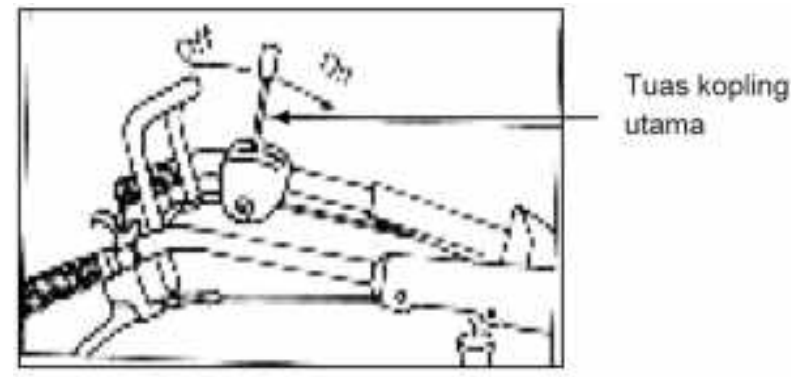

2. Menghidupkan mesin (enjin)

Traktor yang menggunakan enjin diesel dihidupkan dengan engkol. Mula-mula engkol dipasang pada poros engkol (cranksaft). Setelah gas dibesarkan sedikit, engkol diputar bebrapa kali sampai putarannya cukup untuk menghidupkan enjin. Sewaktu pemutaran, jangan lupa menarik alat penghilang kompresi (dekompresi lever). Penting : Sebelum kita mengengkol mesin, gigi/ persnelingharus dalam posisi netral.

3. Memajukan traktor 
Traktor baru dapat maju setelah enjin dihidupkan. Setelah itu periksalah apakah gigi/persnelingsudah netral dan kopling pada posisi OFF. Kemudian masukkan gigi/persnelingdengan menggunakan tongkat persnelingke gigi maju $(1,2,3$, atau 4) dan lepaskan atau "ON" - kan pelan-pelan.

4. Menghentikan traktor

Traktor dihentikan cukup dengan menarik tongkat kopling ke belakang, yaitu ke posisi OFF. Kalau dalam posisi OFF traktor belum berhenti, itu berarti penyetelan kopling tidak baik atau pringannya sudah aus. Setelah traktor berhenti, segera netralkan gigi kembali dan turunkan gas (idle)

5. Membelokkan traktor

Membelokkan traktor sewaktu bekerja dilakukan dengan menggunakan steering clutch/kopling pembelok kiri dan kanan. Sewaktu membelok, jangan lupa menurunkan gas dan mengangkat sedikit bagian belakang traktor agar pembelokannya lebih mudah dilaksanakan. Hal ini perlu dilakukan terutama kalau bekerja di tanah yang lembek dan basah. Jika tidak ada kemungkinan traktor terbenam, tekanlah kopling pembelok kiri bila hendak membelok ke kiri dan tekanlah yang sebelah kanan kalau hendak membelok ke kanan.

6. Memundurkan traktor (khusus traktror yang dilengkapi dengan persnelingmundur).

Kopling pada posisi OFF. Setelah itu, masukkan gigi ke gigi mundur (ada tanda R) kemudian lepaskan kopling dan gas jangan terlalu besar.Perhatian : Melepaskan kopling harus pelan-pelan/ jangan sekaligus, hal ini untuk mencegah kecelakaan yang mungkin akan terjadi.

7. Menjalankan lurus ke depan

Traktor harus dapat berjalan lurus ke depan selam beroperasi, ini untuk mempermudah operator dalam melakukan pekerjaan selanjutnya dan mungkin traktor akan sering terbenam, terutama jika tanahnya basah dan lembek. Beberapa hal yang perlu diperhatikan yaitu :

a. Operator harus dapat memandang lurus ke depan.

b. Peganglah pegangan/handle dengan lentur dan tidak kaku.

c. Jika traktor membelok ke kiri atau ke kanan, tekanlah segera kopling pembelok kanan atau kiri.

d. Kalau menggunakan ban karet, usahakanlah agar tekanan angin ban kiri dan kanan sama.

8. Melintasi gelengan/bedengan

Masukkan persnelingrendah, dan lepaskan kopling pelan-pelan, gas jangan terlalu besar. Traktor jangan tegak lurus dengan gelengan, tetapi agak miring sedikit dan rotary jangan berputar. Perhatian : Bila traktor terguling dan keadaan sawahnya berair, maka segera turunkan gas atau langsung mematikan mesinnya.

9. Menanjak/menuruni tanah yang miring

Masukkan persnelingke gigi rendah (gigi 1 atau 2). Putaran mesin jangan terlalu tinggi.

Perhatian : Jangan memindahkan gigi sewaktu menanjak, karena ketika kopling ditarik ke belakang (posisi OFF), ada kemungkinan traktor mundur akibat beratnya sendiri. Begitu pula jangan menekan kopling pembelok.

10. Menjalankan traktor pada tanah yang berlumpur

Jangan menekan salah satu koping pembelok (kiri atau kanan) terlalu lama, karena salah satu roda dapat masuk terus ke tanah/Lumpur hingga dapat terbenam.

11. Menggunakan traktor di tanah yang berdebu

Jika traktor digunakan pada tanah yang berdebu, saringan udara (air cleaner) harus sering diperiksa, karena lebih cepat kotor. Oli pada saringan udara tersebut harus segera diganti dan saringannya dibersihkan. 


\section{Traktor Roda Empat}

Traktor roda empat merupakan suatu peralatan yang diciptakan oleh manusia yang sangat bermanfaat untuk membantu meringankan tugas manusia terutamanya pada kegiatankegiatan dibidang pertanian.

\section{Klasifikasi traktor Roda 4 Berdasarkan Fungsinya}

1. Crawler tractor, yaitu traktor dengan roda rantai

2. Standard Row Crop, umum digunakan di berbagai perkebunan

3. High clearance, traktor dengan jarak antara badan traktor dan tanah (ground clearance) yang tinggi, cocok untuk perkebunan sayuran atau perawatan tunas

4. Orchard, traktor yang digunakan di wilayah perkebunan pepohonan yang besar, ukurannya cukup ramping dan mudah membelok

5. Multipurpose, dapat digunakan untuk berbagai keperluan

6. Lawn And Garden, untuk kebun

7. Tree Skidder, digunakan untuk menarik kayu yang baru ditebang

8. Skid Steer Loader, memiliki loader di depannya

9. Four Wheel Drive with front steering wheel, traktor 4WD yang roda depannya lebih kecil dari roda belakang. Traktor tipe ini memiliki traksi yang besar sehingga memiliki tarikan yang kuat.

10. Four wheel drive with equal sized wheel and articulated steel framing. Roda depan dan belakang traktor ini sama besarnya, bisa digunakan untuk lahan yang berat.

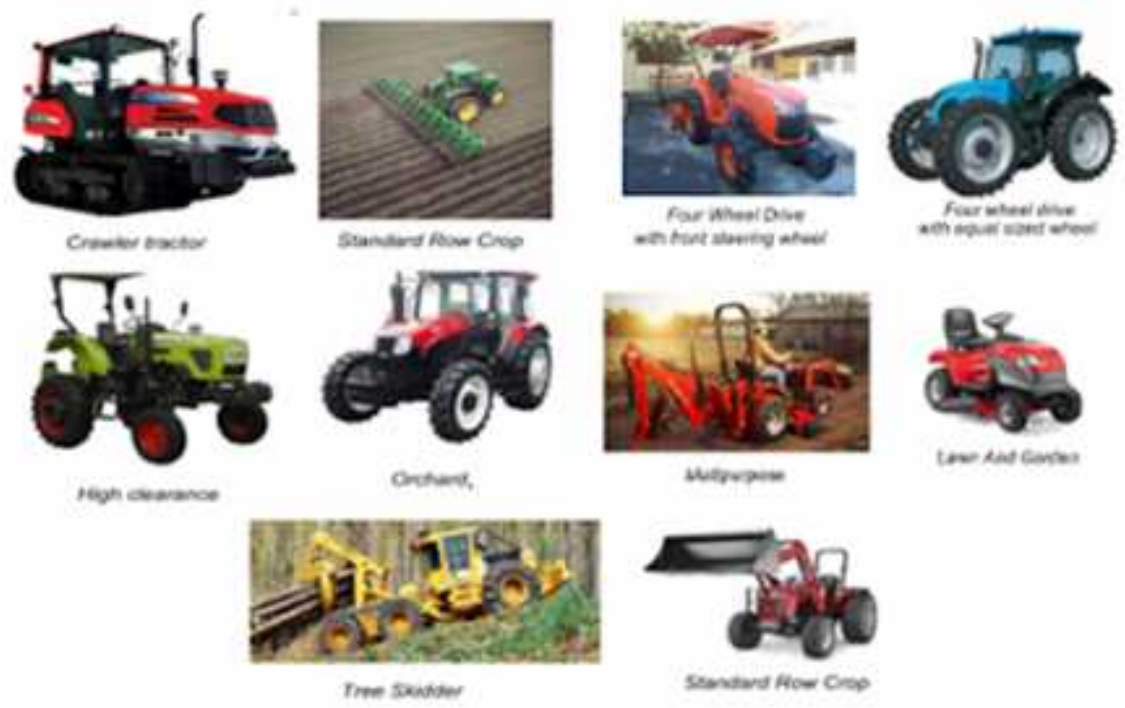

Klasifikasi traktor berdasarkan daya penggeraknya

1. Traktor mikro, <17 tenaga kuda (horsepower)

2. Traktor mini, $17-29 \mathrm{hp}$

3. Traktor sedang, 29-60 hp

4. Traktor besar, 60-107 hp

5. Traktor sangat besar, $>107 \mathrm{hp}$ 


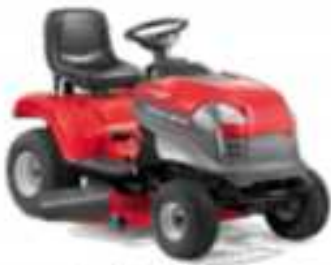

Traktor Mikro

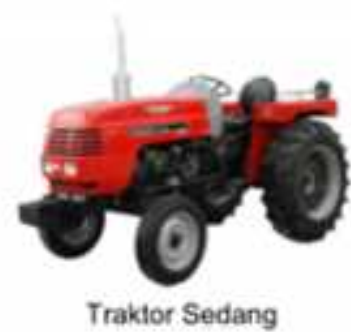

Traktor Sedang

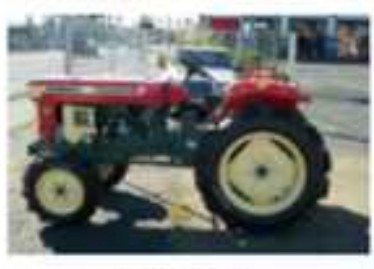

Traktor Mini

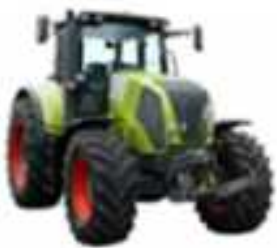

Traktor Besar

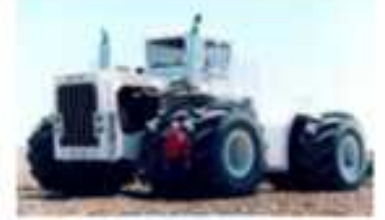

Traktor Sangat Besar

Bagian Traktor Roda Empat (Four Wheel Tractor)

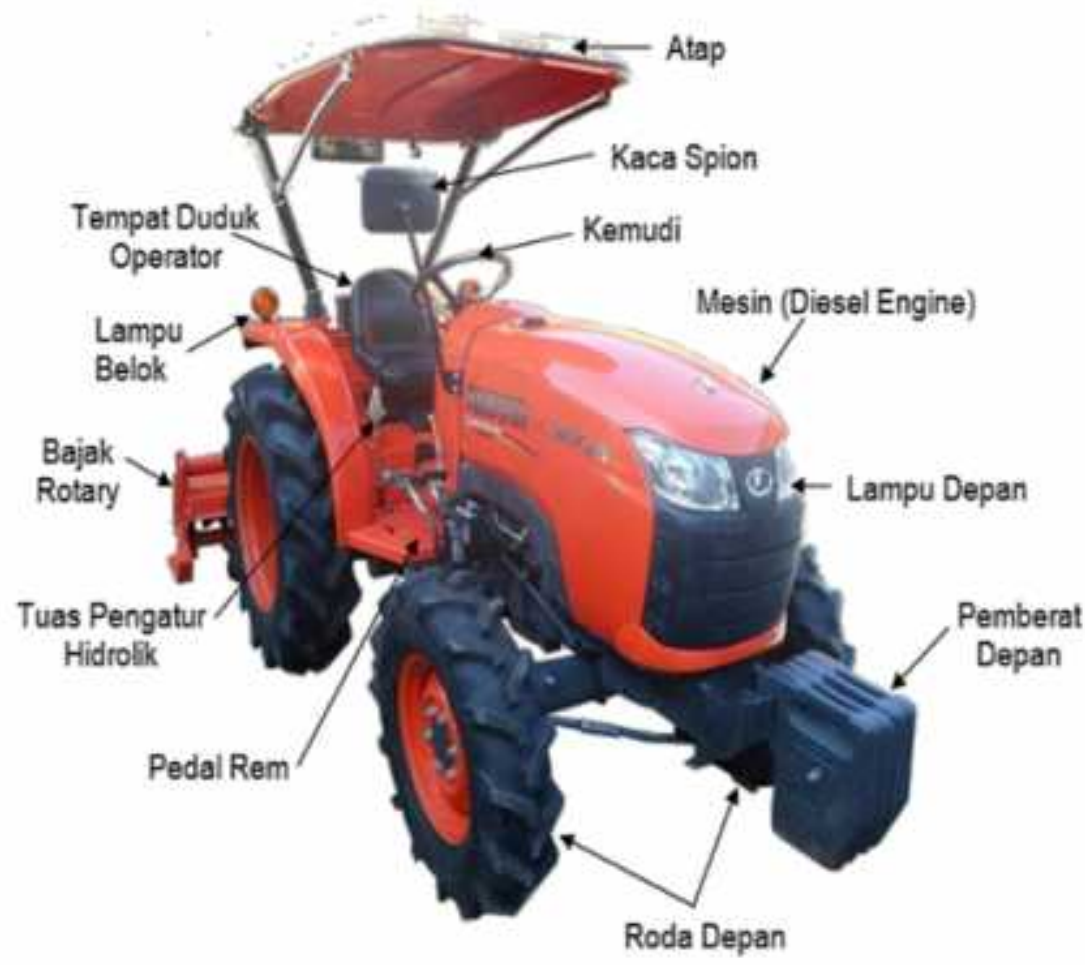

Traktor Tampak Depan 


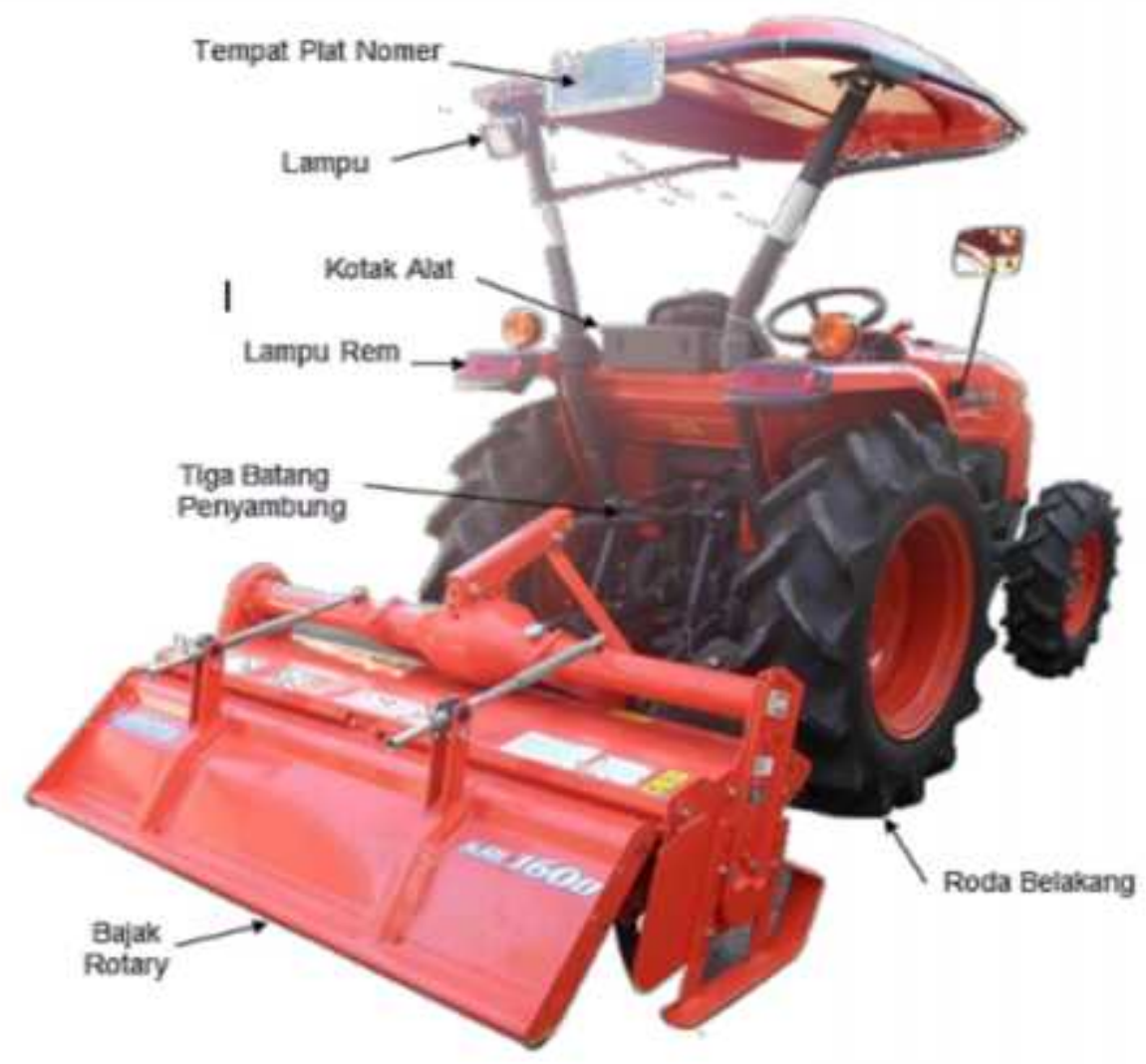

\section{Traktor Tampak Belakang}

\section{Cara mengoperasikan Traktor Roda Empat}

Sebelum mengoperasikannya sebaiknya kita mengenal bagian-bagian pengendali atau instrument lainnya yang berkaitan dengan pengoperasian traktor roda empat.

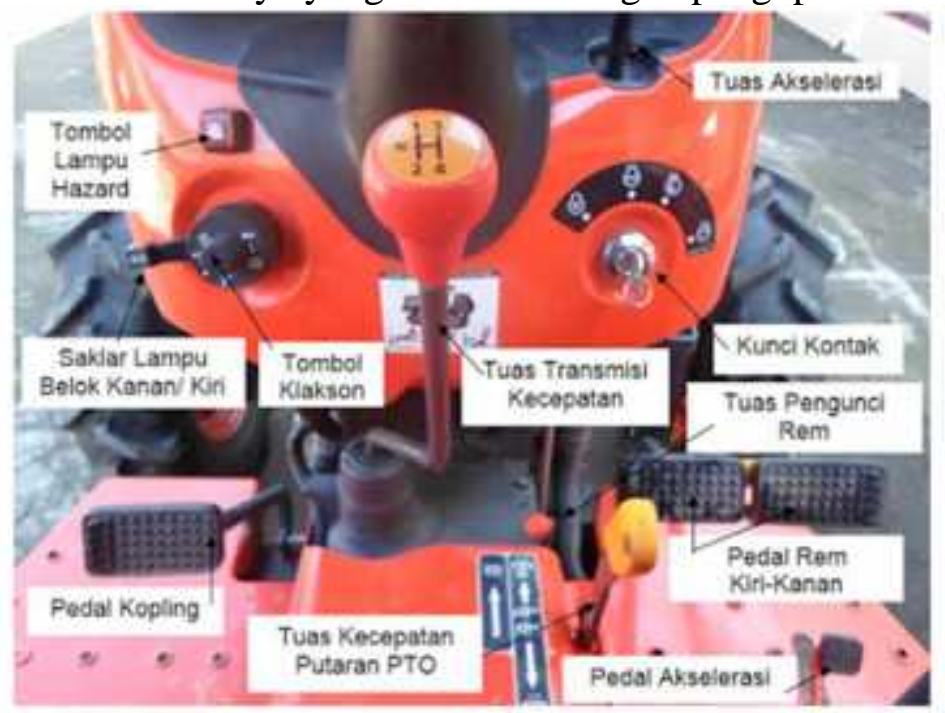

\section{Menghidupkan Mesin Traktor}

1. Duduklah yang baik ditempat duduk

2. Pasang rem parkir

3. Semua tongkat pengatur harus pada posisi netral

4. Masukkan kunci kontak dan putar ke kanan ke arah "on” lihatlah apakah lampu penunjuk tekanan oli sudah menyala 
5. Injak penuh pedal kopeling dan putar kunci kontak ke kiri ke arah "preheater" selama kurang lebih 10-20 detik. Perhatikan apakah indikator pemanas pendahuluan berpijar yang menandakan ruang bakar sudah cukup dipanaskan.

6. Putar kunci kontak ke arah kanan ke posisi "start", maka starter motor akan memutar mesin. Setelah mesin hidup segera lepaskan kunci kontak sehingga kunci kontak akan kembali ke posisi "on" dengan sendirinya.

7. Setelah mesin hidup lampu pengontrol tekanan oli harus padam, bila tetap menyala, matikan segera mesin dan periksa sistem pelumasan

\section{Menjalankan Traktor (Simple Driving)}

1. Injak penuh pedal kopling

2. Pindahkan tongkat pengubah kecepatan utama dan tongkat pengubah kecepatan PTO ke kecepatan yang diinginkan.

3. Lepaskan rem parkir

4. Tingkatkan akselerasi mesin dengan menggunakan handel atau pedal akselerasi

5. Lepaskan pedal kopling perlahan-lahan dan traktor akan mulai bergerak.

\section{Mengoperasikan pada saat pengolahan lahan}

1. Pasang bajak sesuai kebutuhan (bajak Singkal atau rotary)

2. Naikkan Putaran Mesin pada kecepatan konstan dengan menggunakan tuas akselerasi tangan

3. Injak kopling, masukkan gigi rendah dan tuas putaran rotari

4. Lepaskan kopling secara perlahan-lahan

5. Jalankan sesuai arah yang diinginkan

6. Bila melakukan pembelokan implement harus diangkat untuk mengindari kerusakan/ patah pada implement.

\section{Menghentikan Traktor}

1. Kurangi kecepatan mesin

2. Injaklah kedua pedal kopeling dan rem, maka traktor akan berhenti.

3. Pindahkan tongkat pengubah kecepatan utama dan PTO ke posisi netral dan lepaskan pedal kecepatan.

4. Hubungkan kembali pengunci pedal kiri dan kanan kemudian rem parkir.

Pengolahan tanah merupakan proses merubah sifat fisik tanah dengan cara memotong, membalik, memecah, atau membongkar tanah, sehingga tanah dapat diolah untuk menanam. Pengertian lain, pengolahan tanah dalam usaha budidaya pertanian bertujuan untuk menciptakan keadaan tanah olah yang siap tanam baik secara fisis, kemis, maupun biologis, sehingga tanaman yang dibudidayakan akan tumbuh dengan baik. Pengolahan tanah terutama akan memperbaiki secara fisis, perbaikan kemis dan biologis terjadi secara tidak langsung. 
Pengolahan tanah dibedakan menjadi dua tahap yaitu : (1) Pengolahan tanah pertama (pembajakan), dan (2) Pengolahan tanah kedua (penggaruan). Dalam pengolahan tanah pertama, tanah dipotong, kemudian dibalik agar sisa tanaman dan gulma yang ada di permukaan tanah terpotong dan terbenam. Kedalaman pemotongan dan pembalikan tanah umumnya antara 15 sampai $20 \mathrm{~cm}$. Pengolahan tanah kedua, bertujuan menghancurkan bongkah tanah hasil pengolahan tanah pertama yang besar menjad lebih kecil dan sisa tanaman dan gulma yang terbenam dipotong lagi menjadi lebih halus sehingga akan mempercepat proses pembusukan.

Pada bab sebelumnya bahwa pengolahan tanah terus berkembang seiring perkembangan zaman. Dahulu manusia menggunakan alat sederhana untuk mengolah tanah, seperti bajak tradisional yang dikaitkan pada kerbau, sapi, atau hewan ternak lainnya. Di setiap daerah memiliki jenis bajak yang berbeda-beda, di Aceh istilah lainnya ialah langa atau langa, terdiri dari beberapa bagian yang terbuat dari kayu, pengoperasiannya menggunakan tenaga kerbau. Selanjtnya alat tradisional yang dipakai untuk mengolah tanah adalah cangkul. Cangkul merupakan alat pengolah tanah yang masih digunakan sampai saat ini walaupn penggunaannya sudah untuk lahan yang sempit atau terbatas. Fungsi cangkul adalah mencungkil, menggali dan meratakan tanah. Kemudian alat tradisional yang dipakai untuk mengolah tanah ialah garu atau garpu tanah. Bentukya seperti garpu dan memiliki tangkai, berfungsi menghaluskan dan meratakan tanah agar tanah siap ditanam. Alat - alat pengolah tanah lainnya adalah cetok tanah, alat ini jarang dipakai sebab penggunaan alat ini hanya untuk mencungkil tanah untuk menanam benih tanaman, alat ini umumnya dipakai untuk tanah perkebunan. Namun kelemahan alat - alat tersebut masih menggunakan tenaga manusia dan hewan ternak yang kurang efektif dan efisien untuk mengolah tanah dalam jumlah yang banyak.

Seiring kebutuhan pangan dunia yang terus meningkat lambat laun orang - orang mulai meninggalkan alat-alat pengolahan tradisional dengan menggunakan tenaga manusia dan hewan beralih ke pengolahan tanah modern yang menggunakan tenaga mesin atau motor bakar sebagai penggerak, dimana alat - alat pengolah tanah yang telah dimodifikasi dikaitkan atau diimplementasikan dengan mesin traktor. Traktor merupakan kendaraan yang dirancang untuk berbagai keperluan, khususnya mengolah tanah dengan sistem PTO (Power Take Out).

Berdasarkan jumlah rodanya traktor dibagi menjadi dua yaitu Traktor roda dua dan Traktor roda empat. Perbedaannya ialah traktor roda dua dioperasikan dengan sistem kopling dimana orang yang mengoperasikannya (operator) memegang kedua stang kendali dan berjalan mengikuti arah traktor, arah traktor dapat dibelokkan kekiri dan kekanan dengan menekan tuas yang ada dibawah stang kendali, jika ke kiri maka tuas kiri yang ditekan, jika kekanan maka tuas kanan yang ditekan. Berbeda dengan traktor roda empat yang sistem pengoperasiaanya dengan sistem kemudi seperti mobil. Kedua traktor tersebut diimplementasikan dengan alat-alat pengolah tanah seperti bajak singkal, bajak piring, bajak rotari. Adapun kelebihan masing-masig traktor tersebut ialah traktor roda dua : 1 . Konstruksinya sederhana dengan menggunakan motor listrik diesel 4 langkah, 2. Ringan dan mudah dikemudikan, 3. Cocok digunakan di sawah, ladang, lereng-lereng pegunungan. Kelemahan : Tidak efisien apabila digunakan dalam lahan yang luas. Sedangkan Traktor roda empat : 1. Lebih cepat dalam melakukan pengolahan 2. Efisien waktu dan tenaga kerja. Kelemahan : 1. Harga mahal. 
Implemet Traktor dibedakan berdasarkan tahap pengolahannaya yaitu pengolahan tanah pertama dan pengolahan tanah kedua. Masing-masing tahapan memiliki fungsi yang berbeda-beda. Pada pengolahan tanah pertama berfugsi untuk membalikan tanah, menghancurkan tanah dan membongkar tanah, alat-alat yang digunakan dalam pengolahan tanah pertama ialah : bajak singkal, baja piring, bajak rotari, bajak chisel dan bajak sub soil. Sedangkan pada pengolahan tanah kedua berfungsi menggemburkan dan meratakan tanah. Alat-alat yang digunakan pada pengolahan tanah kedua ialah : Garu piring, garu paku, garu pegas, garu rotari, garu khusus, land roller dan pulverizers.

Implement - implement diatas sangat berperan penting dalam pengolahan tanah sebelum dilakukan pengolahan tanah lebih lanjut, agar tanah benar-benar siap untuk digarap atau ditanami benih tanaman. Sehingga unsur hara yang ada pada tanah dapat terserap oleh tanaman.

\section{KESIMPULAN}

Pengolahan tanah awalnya dilakukan secara konvensioal atau secara tradisional, dengan menggunakan tenaga hewan ternak (sapi, kerbau, dan kuda). Seiring dengan perkembangan zaman, pengolahan tanah konvensional diganti dengan pengolahan secara modern menggunakan teknologi yang canggih. Alat-alat sederhana yang umumnya digunakan untuk mengolah tanah seperti cangkul, parang, sabit dan lain-lain, sekarang diganti dengan bajak dan garu yang di gandengkan dengan traktor. Secara empiris zaman dulu manusia menggunakan tenaga hewan untuk membajak dan mengolah tanah. Sekarang tenaga hewan ternak tersebut telah digantikan dengan tenaga mesin. Sehingga pengolahan tanah menjadi lebih efisien dan efektif. Pengolahan tanah merupakan proses merubah sifatsifat fisik tanah dengan cara memotong, membalik, memecah, atau membongkar tanah, sehingga tanah dapat diolah untuk menanam. Pengertian lain, pengolahan tanah dalam usaha budidaya pertanian bertujuan untuk menciptakan keadaan tanah olah yang siap tanam baik secara fisis, kemis, maupun biologis, sehingga tanaman yang dibudidayakan akan tumbuh dengan baik. Pengolahan tanah terutama akan memperbaiki secara fisis, perbaikan kemis dan biologis terjadi secara tidak langsung.

\section{REFERENCE}

Alat dan Mesin Pertanian. Buku Teks Bahan Ajar Siswa

Kementerian Pertanian Badan Penyuluhan Dan Pengembangan Sdm Pertanian. 2015. Traktor Roda Dua (Hand Tractor).

Kementerian Pertanian Badan Penyuluhan Dan Pengembangan Sdm Pertanian. 2015. Traktor Roda Dua (Hand Tractor).

Hariyadi, B. W., Ali, M., \& Nurlina, N. (2017). Damage Status Assessment Of Agricultural Land As

A Result Of Biomass Production In Probolinggo Regency East Java. ADRI International Journal Of Agriculture, 1(1).

Pratiwi, Y. I., Ali, M., Setiawan, M. I., Budiyanto, H., \& Sucahyo, B. S. (2017). Urban Agriculture Technology to Support Urban Tourism. ADRI International Journal Of Agriculture, 1(1). 